NBER WORKING PAPER SERIES

CREDIT DEFAULT SWAPS, AGENCY PROBLEMS, AND MANAGEMENT INCENTIVES

\author{
Jongsub Lee \\ Junho Oh \\ David Yermack \\ Working Paper 24064 \\ http://www.nber.org/papers/w24064
}

\author{
NATIONAL BUREAU OF ECONOMIC RESEARCH \\ 1050 Massachusetts Avenue \\ Cambridge, MA 02138 \\ November 2017
}

Part of this paper was written while David Yermack was serving as a Visiting Professor at Erasmus University Rotterdam. The views expressed herein are those of the authors and do not necessarily reflect the views of the National Bureau of Economic Research.

At least one co-author has disclosed a financial relationship of potential relevance for this research. Further information is available online at http://www.nber.org/papers/w24064.ack

NBER working papers are circulated for discussion and comment purposes. They have not been peer-reviewed or been subject to the review by the NBER Board of Directors that accompanies official NBER publications.

(C) 2017 by Jongsub Lee, Junho Oh, and David Yermack. All rights reserved. Short sections of text, not to exceed two paragraphs, may be quoted without explicit permission provided that full credit, including $\odot$ notice, is given to the source. 
Credit Default Swaps, Agency Problems, and Management Incentives

Jongsub Lee, Junho Oh, and David Yermack

NBER Working Paper No. 24064

November 2017

JEL No. G30,G33,G34,J33,M52

\begin{abstract}
$\underline{\text { ABSTRACT }}$
We show in a theoretical model that credit default swaps induce managerial agency problems through two channels: reducing the opportunity for managers to transfer value to equityholders from creditors via strategic default, and reducing the intensity of monitoring by creditors, which leads to greater CEO diversion of assets as perquisites. We further show that boards can use compensation awards that increase managerial performance incentives (delta) and risk-taking incentives (vega) in order to mitigate these two agency problems, with increases in managerial vega being particularly useful to alleviate the strategic default-related agency problem. We study equity compensation awards to CEOs of S\&P 1500 companies during 2001-2015 and find that they occur in patterns consistent with these predictions.

Jongsub Lee

Warrington College of Business

Department of Finance

PO Box 117168, STZ 315E

jongsub.lee@warrington.ufl.edu

Junho Oh

Warrington College of Business

Bryan Hall 100

Gainesville, FL 32611-7150

junho.oh@warrington.ufl.edu

David Yermack

Stern School of Business

New York University

44 West Fourth Street, Suite 9-160

New York, NY 10012

and NBER

dyermack@stern.nyu.edu
\end{abstract}




\section{Credit default swaps, agency problems, and management incentives}

\section{Introduction}

Credit default swaps (CDS) are insurance contracts between two parties with contingent payoffs referenced to future credit events of the underlying entity. Credit events that trigger CDS payments are potentially endogenous, since they may occur as outcomes of unobserved interactions between shareholders and creditors. Several studies recently demonstrate that CDS, once issued, may affect bargaining between shareholders and creditors on an ongoing basis. Since CDS provide creditors with a form of default insurance, they could strengthen their bargaining power in debt negotiations, which in turn could generate significant feedback effects on corporate financial policies. Lenders who heavily hedge their debt exposure with CDS become "empty creditors" (Hu and Black, 2008; Bolton and Oehmke, 2011), who may frequently reject debt exchange offers from shareholders in order to avail themselves of voting rights that may attach during bankruptcy (Danis and Gamba, 2017). Such feedback effects of CDS on various corporate policies have been extensively documented, including increasing corporate leverage (Saretto and Tookes, 2013), more frequent outright liquidations (Subrahmanyam, Tang, and Wang, 2014), and precautionary corporate liquidity management (Subrahmanyam, Tang, and Wang, 2017) following the onset of CDS trading for the debt of a specific firm. Importantly, these studies rely on the inception of CDS trading as an identification strategy, since the listing of a new CDS contract occurs as a result of decisions taken by third-party market makers who typically have no connection with the firm's managers.

Recent literature has focused on conflicts between shareholders and creditors in the presence of CDS, but these papers have generally overlooked potential agency problems arising between shareholders and managers. This paper demonstrates that two types of managerial 
agency problems may occur as a result of CDS introduction. First, managers may engage in less strategic debt default than optimal, since creditors will bargain harder due to the presence of the CDS insurance contract. Second, creditors may tend to monitor managers with reduced intensity, since they become less concerned about the consequences of nonrepayment once they have access to CDS insurance. We present a theoretical model of how CDS affects the incentives for managers to divert assets in the form of perquisites, and we show that agency problems tend to increase through both of these channels. We then use a sample of S\&P 1500 firms between 2001-15 to study whether boards change CEO compensation awards after CDS are introduced.

As our key measures for a CEO's risk-taking and value enhancement incentives, we compute the deltas and vegas for new stock and stock option compensation awards to CEOs of our sample firms. In regression analysis we find that managerial vega increases by $133 \%$ from its sample average following the inception of CDS trades. Moreover, we find that both managerial option and share deltas significantly increase after CDS introduction, leading to an increase in overall managerial delta. We find a $\$ 41,000$ increase in the CEO's wealth from these newly granted incentive contracts when the underlying stock price increases by one dollar.

Increasing both the CEO's effective ownership and risk-taking incentives helps to mitigate the new agency problems between managers and shareholders. However, if we focus on the agency problem arising from the extinguishment of the shareholders strategic default option, those two contractual adjustments affect the manager differently. The agency cost induced by strategic default is mainly driven by managerial actions that increase the probability of default. Since greater effective ownership only motivates the manager in non-default states, it has little impact on the manager's motivation to threaten creditors with a default. In contrast, greater risk-taking incentives are effective in this setting. Our empirical evidence is consistent with this conjecture, as we find that for firms with valuable strategic default options, stock option grants (which have nonzero vegas) increase significantly after CDS 
inception while restricted stock grants (which have zero vega) do not change significantly.

We conduct a robustness test to alleviate concerns about sample selection bias and the influence of confounding endogenous market forces. For example, one could argue that because CDS contracts are not created randomly, our results are driven by omitted firm-level characteristics. We address these selection issues by using an instrumental variable approach as found in studies such as Minton, Stulz, and Williamson (2009), Saretto and Tookes (2013), and Subrahmanyam et al. (2014). We show that our results continue to hold after they are re-estimated in an instrumental variables framework.

Our paper, which is mainly focused on a theoretical model of agency problems related to CDS, complements two recent empirical studies of the topic, Colonnello (2017) and Chen, Leung, Song, and Avino (2017). These papers focus on the implications of reduced creditor monitoring after the inception of CDS, which is one of the two agency problems that we highlight in our model (the other agency problem, overlooked in these two papers, is related to the reduced opportunity for strategic default). While these papers test similar hypotheses about the need to increase managerial vegas to counteract the agency problems of CDS, they reach opposite conclusions, with one paper estimating that managerial vegas increase after the introduction of CDS, while the other paper estimates that vegas decrease.

Our results emphasize the importance of managerial incentives and agency problems when analyzing the real effects of CDS. In most of the published literature to date, the documented real effects of CDS occur in an environment that is assumed not to reflect agency costs between managers and shareholders. We believe our results shed light an overlooked and important aspect of CDS, namely how they create agency problems and how boards adjust management compensation to mitigate these effects.

The remainder of this paper proceeds as follows. Section 2 introduces our hypotheses with a simple model. Section 3 describes our data. Section 4 presents our empirical analysis. Section 5 studies the robustness of our findings to adjustments for endogeneity concerns associated with CDS trades. We provide our conclusions in Section 6 . 


\section{Hypothesis development}

\subsection{A simple model of CDS agency}

We develop a simple, intuitive model that illustrates how empty creditors whose debt positions are over-insured by CDS could exacerbate managerial agency problems. ${ }^{1}$ Actors in the model include a risk-neutral CEO (the agent), shareholders (principals), and creditors of a firm. We consider equity of a firm as a call option on the underlying assets based on Merton (1974), while strategic default is a viable option to shareholders (Anderson and Sundaresan, 1996). We assume that firm value $V_{t}$ follows the following geometric Brownian motion: $d V_{t}=\mu V_{t} d t+\sigma V_{t} d W_{t}$ where $\mu=0$ for simplicity. The firm issues zero-coupon debt with face value of $K$, but given the strategic debt renegotiation possibility between shareholders and creditors, the effective default boundary of the firm is not necessarily set at $K$. If successful, strategic debt renegotiation lowers the default threshold below $K$. The risk-free rate and dividend yield are set to be zero for simplicity, without loss of generality.

The model has two periods. At time 0, shareholders provide the CEO either shares or options as an incentive contract, $g(\alpha, \sigma)$, to induce desirable actions from the CEO at time 1, with $\sigma>0$ and $0<\alpha<1$, respectively, denoting the level of corporate risk and the CEO's ownership. The zero-coupon debt matures at time 1. At time 0 the CEO chooses project risk, and at time 1 when the state is realized, (s)he can divert $\phi V_{1}$ out of the firm as perquisites with a detection technology of the diversion given by $\frac{\theta}{2} \phi^{2} V_{1}$, where $0<\phi<1$, and $\theta>1$ is the intensity of creditors' monitoring over the CEO. The CEO's incentive compensation package is expressed as $\alpha E_{0}\left[S\left(V_{1}, K, \alpha, \phi, \sigma\right)\right]$, where $S$ is the total equity value of the firm. ${ }^{2}$

\footnotetext{
${ }^{1}$ Our model stylizes the creditors' behavior when their debts are over-insured by CDS; CDS creditors never permit successful private debt workouts. In other words, our model weighs the empty creditor cost of CDS relatively more heavily, which may matter more when a firm's value falls below the standard default threshold implied by the absolute priority in default. It relatively underestimates the potential commitment benefits of CDS that matter more when the firm's value exceeds the default threshold (Bolton and Oehmke, 2011). See more details on this modeling feature in our Appendix B.

${ }^{2}$ In the structural credit models, shares (options) are represented as a call option (compound call option) on the underlying assets. Given that newly granted options are near at-the-money, both contracts have a structural representation as a call option on the underlying firm value, yet, with different strike levels. Specifically, the relation of firm value and a share can be expressed as $S=[V-K]^{+}$whereas an option is
} 
If the firm approaches default, the CEO could renegotiate the firm's debt down to $K(1-L)$ from $K$ with creditors, where $0<L<1$ is the fractional cost of bankruptcy. The success probability of strategic default is $\xi \in[0,1]$, which is assumed to be uniformly distributed over its support. As shown in Bolton and Oehmke (2011), the presence of CDS decreases $\xi$ toward zero. Without loss of generality, we assume $\xi_{C D S}=0$. Shareholders want to minimize the expected agency cost:

$$
\begin{array}{ll}
\min _{g(\alpha, \sigma)} & E_{0}\left[\phi V_{1}\right] \\
\text { s.t. } & \phi, \sigma \in \operatorname{argmax} \alpha E_{0}\left[S\left(V_{1}, K, \alpha, \phi, \sigma\right)\right]+E_{0}\left[\phi V_{1}\right]-\frac{\theta}{2} E_{0}\left[\phi^{2} V_{1}\right]
\end{array}
$$

$\alpha S\left(V_{1}, K, \alpha, \phi, \sigma\right)$ is the CEO's monetary compensation from the firm at time 1 , which takes the functional form of $\alpha\left[V_{1}(1-\phi)-K\right]^{+}$if the absolute priority rule holds in bankruptcy.

\subsubsection{The CEO's shirking decision at $t=1$}

At time 1, the firm could be in one of the following three states: (i) solvent $\left(V_{1}(1-\phi) \geq K\right)$ , (ii) strategic default $\left(K(1-L) \leq V_{1}(1-\phi)<K\right)$, and (iii) default $\left(V_{1}(1-\phi)<K(1-L)\right)$.

If a firm is solvent at time 1, the first order condition of the CEO's incentive problem with respect to $\phi$ is

$$
\begin{gathered}
\frac{\partial}{\partial \phi}\left(\alpha\left(V_{1}(1-\phi)-K\right)+\phi V_{1}-\frac{\theta}{2} \phi^{2} V_{1}\right)=0 \\
\phi^{*}=\frac{1-\alpha}{\theta}
\end{gathered}
$$

If $K(1-L) \leq V_{1}(1-\phi)<K$, and the firm successfully renegotiates the debt $K$ with the creditors, $K$ in the equation (1) is replaced with $K(1-L)$, and $\phi^{*}=\frac{1-\alpha}{\theta}$.

If the firm fails in debt renegotiation, or is in the default state, the first order condition $\overline{O=\left[[V-K]^{+}-S_{E}\right]^{+}=\left[V-\left(K+S_{E}\right)\right]^{+}}$where $V$ is firm value, $S$ is an underlying stock price, and $S_{E}$ is the exercise price of the option. $K$ is the face value of corporate debt. 
of the CEO's problem with respect to $\phi$ is

$$
\begin{gathered}
\frac{\partial}{\partial \phi}\left(\phi V_{1}-\frac{\theta}{2} \phi^{2} V_{1}\right)=0 \\
\phi^{*}=\frac{1}{\theta}
\end{gathered}
$$

Thus, the CEO's optimal level of fractional perquisite at time $1, \phi^{*}$, is given as:

$$
\phi^{*}= \begin{cases}\frac{1-\alpha}{\theta} & \text { if } V_{1} \geq \bar{V}_{K(1-L)} \\ \frac{1}{\theta} & \text { if } V_{1}<\bar{V}_{K(1-L)}\end{cases}
$$

where $\bar{V}_{K(1-L)}=\frac{K(1-L)}{1-\frac{1-\alpha}{\theta}}$.

\subsubsection{Expected agency cost at $t=0$}

Define $\bar{V}_{K}=\frac{K}{1-\frac{1-\alpha}{\theta}}$. The ex-ante expected agency cost to shareholders is given as:

$$
\begin{aligned}
& \Omega=E_{0}\left[\phi^{*} V_{1}\right] \\
& =E_{0}\left[\phi^{*} V_{1} \mid V_{1} \geq \bar{V}_{K}\right] \cdot \operatorname{Pr}\left(V_{1} \geq \bar{V}_{K}\right) \\
& +E_{0}\left[\phi^{*} V_{1} \mid \bar{V}_{K(1-L)} \leq V_{1}<\bar{V}_{K}\right] \cdot \operatorname{Pr}\left(\bar{V}_{K(1-L)} \leq V_{1}<\bar{V}_{K}\right) \\
& +E_{0}\left[\phi^{*} V_{1} \mid V_{1}<\bar{V}_{K(1-L)}\right] \cdot \operatorname{Pr}\left(V_{1}<\bar{V}_{K(1-L)}\right) \\
& =\frac{1-\alpha}{\theta} V_{0} N\left(d_{1}\left(\phi_{1}, K\right)\right) \\
& +\left(\xi \frac{1-\alpha}{\theta}+(1-\xi) \frac{1}{\theta}\right) V_{0}\left[N\left(d_{1}\left(\phi_{1}, K(1-L)\right)\right)-N\left(d_{1}\left(\phi_{1}, K\right)\right)\right] \\
& +\frac{1}{\theta} V_{0}\left[1-N\left(d_{1}\left(\phi_{1}, K(1-L)\right)\right)\right] \\
& =\frac{1}{\theta} V_{0}-\frac{\alpha}{\theta} V_{0} N\left(d_{1}\left(\phi_{1}, K\right)\right)-\frac{\xi \alpha}{\theta} V_{0}\left[N \left(d_{1}\left(\phi_{1}, K(1-L)\right)-N\left(d_{1}\left(\phi_{1}, K\right)\right]\right.\right.
\end{aligned}
$$

where $\mathrm{N}(\cdot)$ is the c.d.f. of the standard normal distribution. $\phi_{1}=\frac{1-\alpha}{\theta}$ and $d_{1}(\phi, K)=$ $\frac{\ln \left(\frac{V_{0}(1-\phi)}{K}\right)+\frac{\sigma^{2}}{2}}{\sigma}$.

The expected agency cost is the sum of the three agency costs, respectively, under the 
solvent, strategic default, and default states. It should be noted that the second term in the equation (2), $\left(\xi \frac{1-\alpha}{\theta}+(1-\xi) \frac{1}{\theta}\right) V_{0}\left[N\left(d_{1}\left(\phi_{1}, K(1-L)\right)\right)-N\left(d_{1}\left(\phi_{1}, K\right)\right)\right]$, shows that the effective level of the CEO's perquisite in the strategic default state is the probabilistic weighted average of the CEO's perquisite $\frac{1-\alpha}{\theta}$ with probability of $\xi$ (i.e., success in strategic renegotiation) and $\frac{1}{\theta}$ with a probability of $1-\xi$ (i.e., strategic renegotiation failure).

Proposition 1. [CDS and Agency] CDS induce the following two types of agency problems: a) An agency problem due to the foregone strategic default options to shareholders $\left(\frac{\partial \Omega}{\partial \xi}<0\right)$, and

b) an agency problem due to reduced creditor monitoring intensity $\left(\frac{\partial \Omega}{\partial \theta}<0\right)$.

Proof. See Appendix A.

After CDS are introduced, the absolute priority rule in bankruptcy is more likely $(\xi \downarrow)$, and the creditors' monitoring gets weaker $(\theta \downarrow)$, due to the well-known empty creditors' problem (Hu and Black, 2008; Bolton and Oehmke, 2011; Subrahmanyam et al., 2014). Those changes induce two types of agency problems. First, a decrease in the probability of successful debt renegotiation leads to more frequent liquidations, making the CEO have stronger incentives to divert resources from the firm (i.e., ex post dilution of the CEO's managerial incentive). Second, the reduced monitoring intensity of creditors with CDS would also lead to the increasing resource diversion by the CEO. ${ }^{3}$

Proposition 2. [Managerial Compensation Adjustment] To lower the agency cost that rises after CDS trades, shareholders are more likely to

\footnotetext{
${ }^{3}$ As CDS reduce the strategic default threat by shareholders, the introduction of CDS could increase the debt value. However, in our model where CDS also reduce creditors' monitoring intensity, debt value could decrease as the CEO could be over-shirking following the inception of CDS trades. This implies that simply re-capitalizing the firm's leverage ratio downward does not necessarily eliminate the CDS agency problems. This intuition holds even in the multi-period setting when creditors' potential gains from reduced strategic default are outweighed by the cost of lax monitoring by creditors on the CEO. See Appendix B for the detailed analytical illustration of this debt value analysis before and after the CDS introduction.
} 
a) increase the effective ownership of the CEO $\left(\frac{\partial \Omega}{\partial \alpha}<0\right)$, and/or

b) increase the CEO's risk-taking incentive $\left(\frac{\partial \Omega}{\partial \sigma}<0\right)$ if $\sigma^{2}>2 \ln \left(\frac{V_{0}\left(1-\phi_{1}\right)}{K(1-L)}\right)$.

Proof. See Appendix A.

Proposition 2 states that regardless of the source of the CDS agency problem, an optimal contract that brings the expected agency cost down to its pre-CDS level requires higher managerial ownership $\left(\frac{\partial \Omega}{\partial \alpha}<0\right)$ and higher managerial risk-taking incentive for the CEO $\left(\frac{\partial \Omega}{\partial \sigma}<0\right)$. The latter risk-incentive approach is particularly useful for the relatively risky firms $\left(\sigma^{2}>2 \ln \left(\frac{V_{0}\left(1-\phi_{1}\right)}{K(1-L)}\right)\right)$. In our model, the level of perquisites $\phi^{*}$ could be reduced by the CEO's ownership $(\alpha)$ mainly in the solvent states. As the CEO ownership increases, the agency problem in those solvent states is mitigated due to the incentive alignment between shareholders and the CEO. At the same time, a higher volatility of a firm $(\sigma)$ reduces the ex ante probability of default, thereby inducing the greater ex ante ownership of the CEO. With this increasing ex ante skin-in-the-game of the CEO, the higher $\sigma$ could mitigate the CDS agency problem.

\subsubsection{Strategic default, CDS agency, and the relative efficacy of contractual remedies}

The net increase in the expected agency cost following the CDS trades, which constrain the shareholders' strategic default $\left(\xi \downarrow \xi_{C D S}\right.$ with $\left.\frac{\partial \Omega}{\partial \xi}<0\right)$, can be expressed as

$$
\Omega_{\xi}=\int_{\xi}^{\xi_{C D S}} \frac{\partial \Omega}{\partial \xi} d \xi
$$

where $\frac{\partial \Omega}{\partial \xi}$ is the instantaneous increase in the CDS agency problem due to the reduced strategic default probability.

Our Proposition 2 showed that the total agency cost $(\Omega)$ increases after the CDS inception, but the cost can be reduced by increasing managerial ownership and/or firm volatility. Proposition 3 below identifies which of these two approaches is likely to be more effective. 
Proposition 3. A particular type of the CDS agency problem that is associated with the reduced intensity of strategic default $\left(\Omega_{\xi}\right)$ can be effectively reduced by a contractual arrangement that increases the CEO's risk-taking incentives, i.e., $\frac{\partial^{2} \Omega}{\partial \sigma \partial \xi}>0$, and thus, $\frac{\partial \Omega_{\xi}}{\partial \sigma}<0$. By contrast, increase in $\alpha$ does not necessarily reduce $\Omega_{\xi}$.

Proof. See Appendix A.

The key intuition of Proposition 3 is that increasing firm risk $(\sigma)$ makes the interval of strategic default $\left(N\left(d_{1}\left(\phi_{1}, K(1-L)\right)\right)-N\left(d_{1}\left(\phi_{1}, K\right)\right)\right)$ narrower, which, in turn, reduces the effect of strategic default on total agency cost $(\Omega)$ - i.e., $\sigma$ alleviates the incremental increase in the default probability due to the foregone strategic default following CDS inception. However, increasing managerial ownership $(\alpha)$ cannot effectively curb the CEO's perquisites. That is because CDS increase the probability of default, while $\alpha$ can reduce the CEO's perquisites mainly in the non-default states.

Figure 1 graphically illustrates this point. ${ }^{4}$ The line segments on the cross-section lying on the $\xi-\Omega$ plane represent the relations between the probability of strategic default $(\xi)$ and the total agency cost $(\Omega)$. The slope of each horizontal line segment corresponds to $\frac{\partial \Omega}{\partial \xi}$, which is the instantaneous increase in the agency problem due to the foregone strategic default after CDS introduction. The first figure shows that as CEO's ownership increases $(\alpha)$, the sensitivity of the agency problem to strategic default becomes stronger $\left(\frac{\partial^{2} \Omega}{\partial \alpha \partial \xi}<0\right) .{ }^{5}$

In contrast, the bottom figure shows that the slope of the line segments on the crosssection lying on the $\xi-\Omega$ plane becomes flatter when $\sigma$ increases. This slope change implies $\frac{\partial^{2} \Omega}{\partial \sigma \partial \xi}>0$ as in Proposition 3 - i.e., increasing firm volatility mitigates the CDS agency problem that is associated with strategic default.

\footnotetext{
${ }^{4}$ The relevant parameters are set as follows: $V_{0}=100, K=40, L=0.4, \sigma=0.4, \alpha=0.1$, and $\theta=1.4$.

${ }^{5}$ It should be noted, however, that in the same graph, the increase in $\alpha$ effectively reduces the "total" agency cost of CDS (i.e., $\frac{\partial \Omega}{\partial \alpha}<0$ ). This is consistent with our statement in Proposition 2.
} 


\subsubsection{Discussion: The nature of the firm volatility $(\sigma)$}

Increasing risk $\sigma$ does not necessarily imply the usual risk-shifting by the managers that may hurt firm value (Jensen and Meckling, 1976). In our model, we do not distinguish the CEO's systematic risk-taking (good risk) from idiosyncratic risk-taking (bad risk). In line with our increasing corporate risk-taking after CDS introduction, Chang, Chen, Wang, Zhang, and Zhang (2017) recently document that CDS induce risk-taking that generates patents with greater economic values. However, as our model assumes risk neutrality for all agents, we cannot identify the nature of the risk taken by the firm's managers.

\subsection{Testable implications}

Proposition 1 shows that expected agency costs increase following CDS introduction. In order to bring these costs down to the pre-CDS level, managerial compensation structure can be adjusted to increase the CEO's ownership and his/her incentive to take greater risk (Proposition 2). These outcomes can be implemented by granting new options and/or shares to the CEO, thereby increasing the CEO's managerial delta and vega (Core and Guay, 2002; Edmans, Gabaix, and Landier, 2009; Coles, Daniel, and Naveen, 2013).

$\mathbf{H}$ 1. The number of newly granted options and shares to the CEO will increase after the CDS inception. These incentive contracts lead to an increase in managerial delta and vega.

An option differs from a share in terms of the level of managerial risk-taking incentives. Since the managerial vega of an option is higher than that of a share, an option is more effective in increasing firm volatility. ${ }^{6}$

Our Proposition 3 shows that among the managerial delta and vega approaches, the vega

\footnotetext{
${ }^{6}$ Again, according to the Merton (1974)'s model, the relation of firm value and a share can be expressed as $S=[V-K]^{+}$whereas that of firm value and an option is $O=\left[[V-K]^{+}-S_{E}\right]^{+}=\left[V-\left(K+S_{E}\right)\right]^{+}$, where $V$ is the firm value, $S$ is the underlying stock price, $S_{E}$ is the exercise price of an option. $K$ is the face value of the firm's discounted bond. For a solvent firm, $\frac{\partial S}{\partial \sigma}<\frac{\partial O}{\partial \sigma}$ holds because the vega of an in-the-money call option decreases as the option's moneyness increases.
} 
approach $\left(\frac{\partial \Omega}{\partial \sigma}\right)$ is particularly effective to reduce agency problem associated with foregone strategic default following CDS inception.

H 2. The $C D S$ association with an increase in option grants will be stronger for firms with valuable strategic default option prior to CDS inception. In contrast, the potential value of strategic default will not imply an association between $C D S$ introduction and an increase in share grants.

\section{Data description}

Our sample consists of 28,707 firm-years from the ExecuComp database between 2001 and 2015. We identify new shares and/or options granted to the CEO each year, including details such as expiration dates and strike prices. If the expiration date is missing, we assume that the maturity is 10 years, unless other data for the firm indicate that it usually grants options with a shorter length, in which case we use that length as the assumed option life. We obtain firm financial data from Compustat, and we use Markit to determine the existence of CDS trading availability for each firm-year. In order to calculate stock price volatility, we merge our sample with CRSP. Finally, we obtain board of directors information from the ISS Directors database.

Our main variables of interest concern the value and slope of the CEO's compensation contract. The managerial delta equals the dollar change (in millions) of the CEO's wealth with respect to one dollar change in the company's stock price, and we calculate it using the derivative of the Black-Scholes formula (the delta of a restricted share equals 1). Similarly, the managerial vega equals the dollar change (in millions) of the CEO's wealth with respect to a 0.01 change in the standard deviation of stock returns. We follow the assumptions of Core and Guay (2002) and compute the deltas and vegas using the specification of Edmans et al. (2009). In most of our models we look at how new compensation awards increase the CEO's delta or vega, since most of our hypothesis tests are predictions about how the 
board adjusts $\mathrm{CEO}$ incentives in response to the inception of CDS trading. Our approach implicitly assumes that the CEO's contract had been calibrated with optimal incentives prior to the introduction of CDS, and that the arrival of CDS in the marketplace causes the board to re-set these delta and vega incentives. More details of the variable definitions and their construction procedures are provided in Appendix C.

Table 1 reports summary statistics for our sample. Our main explanatory variable is an indicator that equals one for firm-years with CDS trading observed in the Markit data, and zero otherwise. We sort our sample into firms with and without CDS and compare their key characteristics. On average, CDS firms are larger than non-CDS firms. ${ }^{7}$ The average book leverage of CDS firms is higher than that of non-CDS firms. The market-to-book ratio and R\&D expenditures of CDS firms are lower on average than those of non-CDS firms, indicating that non-CDS companies are more growth-oriented. Their lower leverage ratio than CDS firms could, therefore, be explained by debt overhang that is particularly burdensome for a growth firm. Table 1 also shows that the managerial deltas and vegas of new compensation awards are higher for CDS firms than for non-CDS firms.

Figure 2 gives an overview on the credit rating distribution of our sample firms in the year prior to their CDS introduction, comparing the distribution to that observed in two years after introduction. It illustrates that firms' ratings tend to decrease after CDS inception, consistent with Subrahmanyam et al. (2014).

\section{Empirical tests}

In this section we examine whether CEO's incentive contracts change before and after the inception of CDS trades. According to Hypothesis 1, managerial effective ownership $(\alpha)$ and risk-taking incentives $(\sigma)$ are likely to increase in order to counteract the agency problems induced by CDS. We use the managerial delta and vega as proxies for a CEO's

\footnotetext{
${ }^{7}$ The size difference in our sample is larger than the one reported in Saretto and Tookes (2013). This is expected as we consider a broader set of firms that include not only S\&P 500 companies but also relatively small, medium-sized companies that are also recorded in the ExecuComp database.
} 
effective ownership and risk-taking incentives, respectively. We also consider the relation between CEO incentive contracts and the CDS agency problem caused by forgone strategic default options, as outlined in Hypothesis 2, which predicts that increases in managerial vega should be closely related to this strategic default-related CDS agency problem. We test these predictions and report our results in the following subsections.

\subsection{CEOs' effective ownership and risk-taking incentives after CDS intro- duction}

Table 2 reports the effect of CDS introduction on a CEO's managerial vega. We use the following OLS and Tobit models for firm $i$ in year $t$ to estimate the CDS introduction effect:

(i) OLS with fixed effects

$$
Y_{i t}=a+b \cdot C D S_{i, t-1}+c \cdot(\text { controls })_{i, t-1}+I_{S I C 3}+\delta_{t}+\epsilon_{i, t}
$$

(ii) Tobit with random effects

$$
Y_{i t}= \begin{cases}a+b \cdot C D S_{i, t-1}+c \cdot(\text { controls })_{i, t-1}+R_{i}+\epsilon_{i, t} & \text { if } \quad Y_{i t}^{*}>0 \\ 0 & \text { Otherwise }\end{cases}
$$

(iii) Tobit with fixed effects

$$
Y_{i t}= \begin{cases}Y_{i t}=a+b \cdot C D S_{i, t-1}+c \cdot(\text { controls })_{i, t-1}+I_{S I C 3}+\delta_{t}+\epsilon_{i, t} & \text { if } \quad Y_{i t}^{*}>0 \\ 0 & \text { Otherwise }\end{cases}
$$

Our outcome variable, $Y_{i t}$, is either the managerial vega or its log-transformed value $(\ln (1+$ managerial vega $))$. We construct this variable using only newly granted options to the $\mathrm{CEO}$ of firm $i$ in year $t$. If the CEO receives no new option in that year, we assign zero to the CEO's managerial vega. By definition, a new share's vega is zero. Our main 
explanatory variable is the CDS indicator, which would capture the cross-sectional difference in our outcome variable $Y_{i t}$. As $Y_{i t}$ is effectively the first difference in temporal dimension for the CEO's aggregate vega in two consecutive years, the point estimate of CDS will capture the difference in differences effect of the CDS introduction. In the OLS with fixed effects (specification (i)), $I_{S I C}$ denotes the vector of industry fixed effects defined at the three-digit standard industrial classifications (SIC). Year fixed effects are denoted by $\delta_{t}$ in the linear OLS regression.

As our main variable, managerial vega, is left-censored and clustered at zero, we further adopt the Tobit regression as follows:

$$
Y_{i t}= \begin{cases}Y_{i t}^{*} & \text { if } \quad Y_{i t}^{*}>0 \\ 0 & \text { Otherwise }\end{cases}
$$

where $Y_{i t}$ is a latent variable. When this latent variable is strictly positive, our outcome variable, $Y_{i t}$, is observed with a nonzero value. To control for potential cross-sectional confounding factors, we either estimate the random effects or fixed effects Tobit models. We follow Mundlak (1978) and Yermack (1995) for the Tobit model with random effects (specification (ii)), where $R_{i}$ denotes the firm-specific random disturbance. In the Tobit model with fixed effects (specification (iii)), we control for the three-digit SIC industry and year fixed effects. ${ }^{8}$

As our baseline firm-level controls, we consider size (the natural logarithm of total assets), market-to-book, book leverage, and three-year quarterly ROA volatility. In the OLS with fixed effects (specification (i)) and the Tobit with fixed effects (specification (iii)), we cluster the standard errors at the firm level. In the Tobit model with random effects (specification (ii)), we report bootstrapped robust standard errors. Our Hypothesis 1 predicts $b>0$.

Results are reported in Table 2. In column (1), we show the effect of CDS introduction on the managerial vega, while we simply control for industry and year fixed effects without

\footnotetext{
${ }^{8}$ In this specification (iii), we are not subject to the incidental parameter problems as our number of fixed effect dummies is fixed and does not grow in the number of firms in our data.
} 
firm-level control variables. The point estimate of 0.040 for the CDS indicator implies that for a firm with CDS trading, its CEO's managerial vega increases by $133 \%$ from the sample average (0.03). This result implies that the dollar change in the CEO's wealth with the newly granted incentive contracts for a 0.01 change in the standard deviation of the firm's stock return is $\$ 40,000$ greater when CDS trade. This result is consistent with our prediction from Hypothesis 1.

In column (2), we include our full list of firm control variables, and we find similar results. The estimated coefficient for the CDS indicator is 0.009 , which is statistically significant at the $1 \%$ level. After converting our dependent variable into the log-transformed value (column (3)), we still obtain a statistically significant and positive point estimate of 0.008 for the CDS indicator. In the remaining columns (4) to (7), we report estimates for models using alternative specifications. We estimate the random effects Tobit models in columns (4) and (5), while we estimate the fixed effects Tobit models in columns (6) and (7). In all columns we find largely consistent results with those reported earlier. In column (4), the point estimate of 0.040 for CDS indicates that on average, the sensitivity of the CEO's wealth with respect to a 0.01 increase in the standard deviation of the firm's stock return is larger by $\$ 40,000$ for CDS firms compared to non-CDS firms. The estimated coefficient of 0.011 for CDS in column (6) further confirms that CEOs of CDS firms are on average receiving $\$ 11,000$ more compensation than those of non-CDS firms, when the firm's stock return volatility increases by 0.01 . These results continue to hold after controlling for industry and year fixed effects. Our results are also robust to the use of log-transformed values of the managerial vega under these various Tobit specifications (see columns (5) and (7)).

In Table 3, we examine whether the CEO's managerial delta increases following the introduction of CDS. In column (1) of the table, the estimated coefficient for the CDS indicator, 0.031, indicates that the change in the CEO's wealth from newly granted options with respect to a one dollar change in the underlying stock price is $\$ 31,000$ after the introduction of CDS. When we focus on the managerial share delta rather than managerial option delta 
in column (3), we find similar patterns - the point estimate for the CDS indicator is 0.010, statistically significant at the $1 \%$ level. When we combine the deltas for both option and share grants, we find a $\$ 41,000$ increase in the CEO's wealth from these new equity incentives when the firms stock price increases by one dollar (column (5)). Overall, our results in Table 3 strongly support our Hypothesis 1. Log-transformation of the dependent variable (managerial delta) does not change our conclusions (see columns (2), (4), and (6)).

\subsection{Incentive contracts and CDS: The relevance of strategic default by share- holders}

We test the extent to which our results are related to the strategic default options that were valuable to shareholders prior to CDS inception. Bolton and Oehmke (2011) demonstrate that CDS reduce strategic defaults by shareholders, because creditors whose debt positions are hedged with CDS have stronger bargaining power against shareholders due to their outside payoff opportunity. This logic implies that a firm's shareholders who see their strategic default opportunity diminish after introduction of CDS in the market are more likely to increase their CEO's managerial vega. This would motivate their CEOs to work harder when facing significant incentive dilutions due to increasing default probability.

Given this background, we empirically explore whether the relation between CDS and managerial vega becomes stronger for firms with valuable strategic default options prior to CDS introduction. Following Davydenko and Strebulaev (2007), we measure the value of strategic default by non-fixed assets (one minus ratio of net PPE to total assets), the market-to-book ratio, R\&D expenditures, and a non-utility indicator (zero if a firm is in utility industry and one otherwise). These proxies capture high liquidation costs (Alderson and Betker, 1995). If non-fixed assets and/or R\&D expenditures are higher, recovery rates in post-default restructuring processes would be lower due to the lower fraction of tangible assets. This implies more valuable strategic default options for shareholders. Recovery 
rates also tend to be lower for growth firms (i.e., high market-to-book firms) and non-utility firms with less valuable tangible assets (Acharya, Bharath, and Srinivasan, 2007). In addition to these recovery rate-related strategic default proxies, we further consider CEO tenure and CEO duality as alternative proxies for the bargaining power of CEOs against creditors (Davydenko and Strebulaev, 2007). These additional strategic default proxies also capture the value of such options to shareholders before CDS are introduced.

Table 4 reports the results of our analysis. We use the difference-in-difference-in-difference specification (i.e., CDS $\times$ Strategic Default Proxy) using the OLS regression with industry and year fixed effects. We find that the CEO's managerial vega significantly increases following CDS introduction, particularly for firms with higher non-fixed asset, market-to-book, non-utility, and the CEO duality indicator (column 1, 2, 4, and 6). Although the other interactions between CDS with R\&D expenditures and CEO tenure are not statistically significant, their signs are consistently positive. Overall, these results in Table 4 are largely consistent with our Hypothesis 2 - forgone strategic default to shareholders in the postCDS trading period is closely related to the option incentives provided to the CEO. When we compute the marginal effect of the same triple difference term (CDS $\times$ Strategic Default Proxy) using the Tobit with random effects (see the bottom row of Table 4), we still find that the estimated marginal effects are all positive. Their estimates are statistically significant for firms with higher non-fixed asset, higher market-to-book ratio, higher R\&D expenditures, and CEO tenure (columns (1), (2), (3), and (5)).

Although not tabulated, we find contrasting and insignificant estimates for the relation between the managerial delta and the strategic default options to shareholders. We find overall negative point estimates for all specifications of the CDS $\times$ Strategic Default Proxy, particularly for the share delta of the CEO rather than the option delta. These untabulated results are also consistent with our predictions in Hypothesis 2. 


\section{Robustness tests}

The introduction of CDS is not random, meaning that our estimates may subject to sample selection biases. To address this possibility, we estimate an instrumental variables model. We adopt a firm's main lenders' foreign exchange derivatives usage as the instrument for CDS. This instrument is widely used in the CDS and corporate finance literature (Minton et al., 2009; Saretto and Tookes, 2013; Subrahmanyam et al., 2014); banks that use foreign exchange derivatives tend to be the net buyers of credit protections (inclusions), while the lenders who use foreign exchange derivatives for hedging purposes are unlikely to be motivated by the reference entity's characteristics (exclusions). To construct our instrument, we first identify the lead arrangers of a syndicated loan for a firm of interest using the DealScan syndicated loan database. ${ }^{9}$ We then search each lead arranger's ultimate parent company using the organizational structure information of banks in the CapitalIQ database. We obtain the data for each parent bank's foreign exchange derivatives usage from the call report at the Federal Reserve Bank of Chicago. ${ }^{10}$

We define the Lender FX derivative as the amount of foreign exchange derivatives for nontrading purposes of the ultimate lender parent. We normalize this amount by the lender's total assets over the past five years. If there are more than two ultimate parents for a lead arranger of a firm, we take their average values. To avoid forbidden regressions, we follow the three-step instrumental variables regression as done in Adams, Almeida, and Ferreira (2009). We report our results in Table 5.

In the first stage regression in column (1), the estimated sign for Lender FX derivative on CDS is positive and statistically significant at the $1 \%$ level. This is consistent with the results documented in existing studies (e.g., Subrahmanyam et al. (2014)). In our second stage regression in column (2), we find a significantly positive point estimate of 0.024 for our

\footnotetext{
${ }^{9}$ We link DealScan borrower information to Compustat firm identifiers using the linking file provided by Chava and Roberts (2008).

${ }^{10}$ https://www.chicagofed.org/banking/financial-institution-reports/commercial-bank-data. Since these commercial bank data do not provide Compustat identifiers, we match the data with Compustat and DealScan information through manual name matches.
} 
CDS indicator, statistically significant at the $1 \%$ level.

\section{Conclusions}

We study how the introduction of credit default swaps may cause agency problems between a firm's CEO and its shareholders, and we analyze whether managerial incentive contracts can serve as a remedy for these agency problems.

We model how the inception of CDS affects the CEO's risk appetite and the incentive alignment between the CEO and shareholders. We demonstrate that a significant increase in creditors' bargaining power due to the default insurance provided by CDS effectively undermines shareholders' strategic default threat. We find that boards revise CEOs' incentive contracts around the time of CDS introduction, largely consistent with the predictions from our model. We find that the CEOs managerial vega significantly increases following the introduction of CDS in both a statistical and an economic sense. We show that this forgone strategic default option, which was valuable to the shareholders in the pre-CDS period, is closely related to the motivation of a firm's board granting increasingly more options to the CEO after CDS introductions.

Our study sheds light on the relative importance of managerial agency problems and incentive contracts when one studies the impact of the empty creditor's problem in the presence of CDS. While a number of theory papers have identified the potential costs of empty creditors with CDS (Hu and Black, 2008; Bolton and Oehmke, 2011), this agency problem has not been documented empirically. And while many studies find positive impacts of CDS on corporate debt capacity and value (Saretto and Tookes, 2013; Danis and Gamba, 2017), we posit that such net positive consequences of CDS could be driven by important omitted factors, including action by a firm's board that recognizes potential agency problems and

adjusts the CEO's contract to counteract them. Our findings therefore help explain why the empirical estimate of the cost of the empty creditors' problem appears to be lower than 
theoretical predictions. Further work in this area would help set a useful micro-foundation for understanding real effects of CDS. 


\section{References}

Acharya, V. V., Bharath, S. T., Srinivasan, A., 2007. Does industry-wide distress affect defaulted firms? Evidence from creditor recoveries. Journal of Financial Economics 85, $787-821$.

Adams, R., Almeida, H., Ferreira, D., 2009. Understanding the relationship between founderceos and firm performance. Journal of Empirical Finance 16, 136-150.

Alderson, M. J., Betker, B. L., 1995. Liquidation costs and capital structure. Journal of Financial Economics 39, 45-69.

Anderson, R. W., Sundaresan, S., 1996. Design and valuation of debt contracts. Review of Financial Studies 9, 37-68.

Bolton, P., Oehmke, M., 2011. Credit default swaps and the empty creditor problem. Review of Financial Studies 24, 2617-2655.

Chang, X. S., Chen, Y., Wang, S. Q., Zhang, K., Zhang, W., 2017. Does financial innovation affect technological innovation? Evidence from credit default swap trading. Unpublished Working Paper .

Chava, S., Roberts, M. R., 2008. How does financing impact investment? The role of debt covenants. The Journal of Finance 63, 2085-2121.

Chen, J., Leung, W. S., Song, W., Avino, D., 2017. Does CDS trading affect risk-taking incentives in managerial compensation? Unpublished Working Paper .

Coles, J. L., Daniel, N. D., Naveen, L., 2013. Calculation of compensation incentives and firm-related wealth using execucomp: Data, program, and explanation .

Colonnello, S., 2017. Internal governance and creditor governance: Evidence from credit default swaps. Second draft (No. 6/2017). Tech. rep., IWH Discussion Papers. 
Core, J., Guay, W., 2002. Estimating the value of employee stock option portfolios and their sensitivities to price and volatility. Journal of Accounting Research 40, 613-630.

Danis, A., Gamba, A., 2017. The real effects of credit default swaps. Journal of Financial Economics .

Davydenko, S. A., Strebulaev, I. A., 2007. Strategic actions and credit spreads: An empirical investigation. The Journal of Finance 62, 2633-2671.

Edmans, A., Gabaix, X., Landier, A., 2009. A multiplicative model of optimal CEO incentives in market equilibrium. Review of Financial Studies 22, 4881-4917.

Hu, H. T., Black, B., 2008. Debt, equity and hybrid decoupling: Governance and systemic risk implications. European Financial Management 14, 663-709.

Jensen, M. C., Meckling, W. H., 1976. Theory of the firm: Managerial behavior, agency costs and ownership structure. Journal of Financial Economics 3, 305-360.

Merton, R. C., 1974. On the pricing of corporate debt: The risk structure of interest rates. The Journal of Finance 29, 449-470.

Minton, B. A., Stulz, R., Williamson, R., 2009. How much do banks use credit derivatives to hedge loans? Journal of Financial Services Research 35, 1-31.

Mundlak, Y., 1978. On the pooling of time series and cross section data. Econometrica: Journal of the Econometric Society pp. 69-85.

Saretto, A., Tookes, H. E., 2013. Corporate leverage, debt maturity, and credit supply: The role of credit default swaps. Review of Financial Studies 26, 1190-1247.

Subrahmanyam, M. G., Tang, D. Y., Wang, S. Q., 2014. Does the tail wag the dog?: The effect of credit default swaps on credit risk. Review of Financial Studies p. hhu038. 
Subrahmanyam, M. G., Tang, D. Y., Wang, S. Q., 2017. Credit default swaps, exacting creditors and corporate liquidity management. Journal of Financial Economics .

Yermack, D., 1995. Do corporations award CEO stock options effectively? Journal of Financial Economics 39, 237-269. 


\section{Appendix A. Proofs}

\section{Proof of Proposition 1}

From equation (2),

$$
\frac{\partial \Omega}{\partial \xi}=-\frac{\alpha}{\theta} V_{0}\left[N \left(d_{1}\left(\phi_{1}, K(1-L)\right)-N\left(d_{1}\left(\phi_{1}, K\right)\right]<0\right.\right.
$$

because $N\left(d_{1}\left(\phi_{1}, K_{1}\right)\right)>N\left(d_{1}\left(\phi_{1}, K_{2}\right)\right)$ for every $0<K_{1}<K_{2}$ and $d_{1}>0$ (non-distressed firm at $t=0)$.

$$
\begin{aligned}
& \frac{\partial \Omega}{\partial \theta}=\frac{\partial}{\partial \theta}\left(E_{0}\left[\phi^{*} V_{1}\right]\right) \\
& =-\frac{1}{\theta^{2}} V_{0}+\frac{\alpha}{\theta^{2}} V_{0} N\left(d_{1}\left(\phi_{1}, K\right)\right)-\frac{\alpha}{\theta} V_{0} n\left(d_{1}\left(\phi_{1}, K\right)\right) \frac{\partial}{\partial \theta} d_{1}\left(\phi_{1}, K\right) \\
& +\frac{\xi \alpha}{\theta^{2}} V_{0}\left[N\left(d_{1}\left(\phi_{1}, K(1-L)\right)\right)-N\left(d_{1}\left(\phi_{1}, K\right)\right)\right] \\
& -\frac{\xi \alpha}{\theta} V_{0}\left[n\left(d_{1}\left(\phi_{1}, K(1-L)\right)\right) \frac{\partial}{\partial \theta} d_{1}\left(\phi_{1}, K(1-L)\right)-n\left(d_{1}\left(\phi_{1}, K\right)\right) \frac{\partial}{\partial \theta} d_{1}\left(\phi_{1}, K\right)\right] \\
& =-\frac{1}{\theta^{2}} V_{0}\left[1-\alpha N\left(d_{1}\left(\phi_{1}, K\right)\right)\right]-\frac{\alpha}{\theta} V_{0} n\left(d_{1}\left(\phi_{1}, K\right)\right) \frac{1-\alpha}{\sigma \theta(\theta+\alpha-1)} \\
& +\frac{\xi \alpha}{\theta^{2}} V_{0}\left[N\left(d_{1}\left(\phi_{1}, K(1-L)\right)\right)-N\left(d_{1}\left(\phi_{1}, K\right)\right)\right] \\
& -\frac{\xi \alpha}{\theta} V_{0}\left[n\left(d_{1}\left(\phi_{1}, K(1-L)\right)\right) \frac{1-\alpha}{\sigma \theta(\theta+\alpha-1)}-n\left(d_{1}\left(\phi_{1}, K\right)\right) \frac{1-\alpha}{\sigma \theta(\theta+\alpha-1)}\right] \\
& =-\frac{1}{\theta^{2}} V_{0}\left[1-\alpha N\left(d_{1}\left(\phi_{1}, K\right)\right)\right]+\left(\frac{\xi \alpha}{\theta^{2}}-1\right) V_{0}\left[N\left(d_{1}\left(\phi_{1}, K(1-L)\right)\right)-N\left(d_{1}\left(\phi_{1}, K\right)\right)\right] \\
& -\frac{\xi \alpha}{\theta} V_{0}\left[n\left(d_{1}\left(\phi_{1}, K(1-L)\right)\right) \frac{1-\alpha}{\sigma \theta(\theta+\alpha-1)}\right]+\frac{\xi \alpha-\alpha}{\theta} V_{0} n\left(d_{1}\left(\phi_{1}, K\right)\right) \frac{1-\alpha}{\sigma \theta(\theta+\alpha-1)} \\
& <0
\end{aligned}
$$

because $n\left(d_{1}\left(\phi_{1}, K_{1}\right)\right)<n\left(d_{1}\left(\phi_{1}, K_{2}\right)\right)$ for every $0<K_{1}<K_{2}$ and $d_{1}>0$. 


\section{Proof of Proposition 2}

From equation (2),

$$
\begin{aligned}
\frac{\partial \Omega}{\partial \alpha} & \\
= & -\frac{1}{\theta} V_{0} N\left(d_{1}\left(\phi_{1}, K\right)\right)-\frac{\alpha}{\theta} V_{0} n\left(d_{1}\left(\phi_{1}, K\right)\right) \frac{\partial}{\partial \alpha} d_{1}\left(\phi_{1}, K\right) \\
- & \frac{\xi}{\theta} V_{0}\left[N \left(d_{1}\left(\phi_{1}, K(1-L)\right)-N\left(d_{1}\left(\phi_{1}, K\right)\right]\right.\right. \\
& -\frac{\xi \alpha}{\theta} V_{0}\left[n\left(d_{1}\left(\phi_{1}, K(1-L)\right)\right) \frac{\partial}{\partial \alpha} d_{1}\left(\phi_{1}, K(1-L)\right)-n\left(d_{1}\left(\phi_{1}, K\right)\right) \frac{\partial}{\partial \alpha} d_{1}\left(\phi_{1}, K\right)\right] \\
= & -\frac{1}{\theta} V_{0} N\left(d_{1}\left(\phi_{1}, K\right)\right)-\frac{\alpha}{\theta} V_{0} n\left(d_{1}\left(\phi_{1}, K\right)\right) \frac{1}{\sigma(\theta+\alpha-1)} \\
& -\frac{\xi}{\theta} V_{0}\left[N \left(d_{1}\left(\phi_{1}, K(1-L)\right)-N\left(d_{1}\left(\phi_{1}, K\right)\right]\right.\right. \\
- & \frac{\xi \alpha}{\theta} V_{0}\left[n\left(d_{1}\left(\phi_{1}, K(1-L)\right)\right) \frac{1}{\sigma(\theta+\alpha-1)}-n\left(d_{1}\left(\phi_{1}, K\right)\right) \frac{1}{\sigma(\theta+\alpha-1)}\right] \\
<0 &
\end{aligned}
$$

$$
\begin{aligned}
& \frac{\partial \Omega}{\partial \sigma} \\
& =-\frac{\alpha}{\theta} V_{0} n\left(d_{1}\left(\phi_{1}, K\right) \frac{\partial}{\partial \sigma} d_{1}\left(\phi_{1}, K\right)\right. \\
& -\frac{\xi \alpha}{\theta} V_{0}\left[n\left(d_{1}\left(\phi_{1}, K(1-L)\right)\right) \frac{\partial}{\partial \sigma} d_{1}\left(\phi_{1}, K(1-L)\right)-n\left(d_{1}\left(\phi_{1}, K\right)\right) \frac{\partial}{\partial \sigma} d_{1}\left(\phi_{1}, K\right)\right]<0
\end{aligned}
$$

for $n\left(d_{1}\left(\phi_{1}, K(1-L)\right)\right)<n\left(d_{1}\left(\phi_{1}, K\right)\right), \frac{\partial}{\partial \sigma} d_{1}\left(\phi_{1}, K(1-L)\right)<\frac{\partial}{\partial \sigma} d_{1}\left(\phi_{1}, K\right)$ for $d_{1}>0$ (nondistressed firms) and $\sigma^{2}>2 \cdot \ln \left(\frac{V_{0}\left(1-\phi_{1}\right)}{K(1-L)}\right)$ (firms with relatively higher volatility). 


\section{Proof of Proposition 3}

From equation (2),

$$
\begin{aligned}
& \frac{\partial^{2} \Omega}{\partial \sigma \partial \xi} \\
& =-\frac{\alpha}{\theta} V_{0}\left[n\left(d_{1}\left(\phi_{1}, K(1-L)\right)\right)\left(-\frac{1}{\sigma^{2}} \ln \left(\frac{V_{0}\left(1-\phi_{1}\right)}{K(1-L)}\right)+\frac{1}{2}\right)\right. \\
& \left.-n\left(d_{1}\left(\phi_{1}, K\right)\right)\left(-\frac{1}{\sigma^{2}} \ln \left(\frac{V_{0}\left(1-\phi_{1}\right)}{K}\right)+\frac{1}{2}\right)\right]>0
\end{aligned}
$$

for $d_{1}>0$ and $\sigma^{2}>2 \cdot \ln \left(\frac{V_{0}\left(1-\phi_{1}\right)}{K(1-L)}\right)$ (firms with relatively higher volatility as conditioned in Proposition 2).

By contrast,

$$
\begin{aligned}
& \frac{\partial^{2} \Omega}{\partial \alpha \partial \xi} \\
& =-\frac{1}{\theta} V_{0}\left[N \left(d_{1}\left(\phi_{1}, K(1-L)\right)-N\left(d_{1}\left(\phi_{1}, K\right)\right]\right.\right. \\
& -\frac{\alpha}{\theta} V_{0}\left[n\left(d_{1}\left(\phi_{1}, K(1-L)\right)\right) \frac{1}{\sigma(\theta+\alpha-1)}-n\left(d_{1}\left(\phi_{1}, K\right)\right) \frac{1}{\sigma(\theta+\alpha-1)}\right]
\end{aligned}
$$

is generally indefinite. However, the equation above is negative when $\sigma$ is sufficiently high, i.e., $\sigma \gg \frac{\alpha}{(\theta+\alpha-1)}$.

Since $\frac{\partial^{2} \Omega}{\partial \alpha \partial \xi}$ and $\frac{\partial^{2} \Omega}{\partial \sigma \partial \xi}$ are independent of $\xi$,

$$
\begin{gathered}
\frac{\partial \Omega_{\xi}}{\partial \alpha}=\int_{\xi}^{\xi_{C D S}} \frac{\partial^{2} \Omega}{\partial \alpha \partial \xi} d \xi=\frac{\partial^{2} \Omega}{\partial \alpha \partial \xi}\left(\xi_{C D S}-\xi\right)>0 \\
\frac{\partial \Omega_{\xi}}{\partial \sigma}=\int_{\xi}^{\xi_{C D S}} \frac{\partial^{2} \Omega}{\partial \sigma \partial \xi} d \xi=\frac{\partial^{2} \Omega}{\partial \sigma \partial \xi}\left(\xi_{C D S}-\xi\right)<0
\end{gathered}
$$

where $\xi>\xi_{C D S}=0$ by assumption. 


\section{Appendix B. Analytical derivation of the debt value change after CDS introduction}

Our model highlights the cost of the empty creditors' problem, which is driven by managerial perquisite consumption following CDS introduction. As the managerial perquisites are motivated by $\alpha<1$ and a limited detection technology $\theta$, our setting differs from Bolton and Oehmke (2011), who assume $\alpha=1$ and a sufficiently high $\theta \gg 1$. Our model features over-shirking of the CEO in anticipation of excessive default following CDS inception. In our model, CDS also reduce the creditors' monitoring intensity, which leads to further CEO over-consumption of perquisites. These two changes around the CDS introduction together imply a reduction in firm value after CDS introduction. As debt holders could anticipate these changes and adjust their debt prices accordingly, any reduction in firm value would be borne by shareholders. Debt values, however, could increase or decrease, depending on whether the increasing payoff to the creditors due to the foregone strategic default option of shareholders outweighs the decreasing payoff to the creditors due to the managerial overshirking. This tradeoff depends on the parameter values. Our model might overestimate the CDS agency problem because CDS could enhance the expected wealth of the debtholders. However, so long as the expected debt value does not increase dramatically following CDS introduction, our models intuition would carry through. As our model aims to capture the agency features that are not modeled in the existing studies (Bolton and Oehmke, 2011), its prediction for debt price changes may not fully conform to the existing studies' predictions. However, this discrepancy doesn't necessarily imply that our model is in conflict with other models. Our model consistently predicts increasing leverage ratio following CDS introduction, and when creditors' monitoring intensity reduction is ignored, our model consistently predicts increasing debt capacity following the CDS introduction. To share all these intuitions, let us calculate the change in debt price after the CDS introduction.

First, assume that creditor monitoring intensity $(\theta)$ does not change after CDS introduc- 
tion. Following CDS introduction, the expected value of debt increases:

$\xi E_{0}\left[\left(V_{1}-\frac{V_{1}}{2 \theta}\right)-K(1-L) \mid \bar{V}_{K(1-L)}(\theta) \leq V_{1}<\bar{V}_{K}(\theta)\right] \cdot \operatorname{Pr}\left(\bar{V}_{K(1-L)}(\theta) \leq V_{1}<\bar{V}_{K}(\theta)\right)>0$

where $\left(V_{1}-\frac{V_{1}}{2 \theta}\right)>K(1-L)$ if $\bar{V}_{K(1-L)}(\theta) \leq V_{1}<\bar{V}_{K}(\theta)$.

Intuitively, Equation (A1) indicates that the creditors benefit from CDS introduction because they can be paid by the remaining firm value $V_{0}\left(1-\frac{1}{2 \theta}\right)$ which is greater than the debt level $K(1-L)$ when strategic debt renegotiation option was available to the shareholders before CDS introduction.

Now consider that creditor monitoring becomes weaker from $\theta_{1}$ to $\theta_{2}$ after CDS introduction $\left(\theta_{1}>\theta_{2}>1\right)$. An increase in the expected value of debt after CDS introduction is

$$
\begin{aligned}
& \left(1-\frac{1}{2 \theta_{2}}\right) V_{0}\left[N\left(d_{1}\left(\phi_{1}\left(\theta_{2}\right), K(1-L)\right)\right)-N\left(d_{1}\left(\phi_{1}\left(\theta_{2}\right), K\right)\right)\right] \\
& -\xi K(1-L)\left[N\left(d_{2}\left(\phi_{1}\left(\theta_{1}\right), K(1-L)\right)\right)-N\left(d_{2}\left(\phi_{1}\left(\theta_{1}\right), K\right)\right)\right] \\
& -(1-\xi)\left(1-\frac{1}{2 \theta_{1}}\right) V_{0}\left[N\left(d_{1}\left(\phi_{1}\left(\theta_{1}\right), K(1-L)\right)\right)-N\left(d_{1}\left(\phi_{1}\left(\theta_{1}\right), K\right)\right)\right] \\
& +K\left[N\left(d_{2}\left(\phi_{1}\left(\theta_{2}\right), K\right)\right)-N\left(d_{2}\left(\phi_{1}\left(\theta_{1}\right), K\right)\right)\right] \\
& +\left(1-\frac{1}{2 \theta_{2}}\right) V_{0}\left[1-N\left(d_{1}\left(\phi_{1}\left(\theta_{2}\right), K(1-L)\right)\right)\right]-\left(1-\frac{1}{2 \theta_{1}}\right) V_{0}\left[1-N\left(d_{1}\left(\phi_{1}\left(\theta_{1}\right), K(1-L)\right)\right)\right]
\end{aligned}
$$

where $\phi_{1}(\theta)=\frac{1-\alpha}{\theta}$.

The terms in the first three rows of Equation (A2) correspond to Equation (A1) after considering the reduced monitoring intensity by creditors. They focus on the debt price changes in the strategic default state $\left(K(1-L) \leq V_{1}(1-\phi)<K\right)$. The term in the fourth row of Equation (A2) implies the change in debt value in solvent state $\left(V_{1}(1-\phi) \geq K\right)$ because of 
weaker monitoring intensity. This term is always negative. ${ }^{11}$ The last row of (A2) indicates the change in debt value in default state $\left(V_{1}(1-\phi)<K(1-L)\right)$, whose sign is indeterminate because weaker monitoring intensity reduces debt value $\left(\left(1-\frac{1}{2 \theta_{2}}\right)<\left(1-\frac{1}{2 \theta_{1}}\right)\right)$, while it increases the probability of default $\left(\left[1-N\left(d_{1}\left(\phi_{1}\left(\theta_{2}\right), K(1-L)\right)\right)\right]>\left[1-N\left(d_{1}\left(\phi_{1}\left(\theta_{1}\right), K(1-L)\right)\right)\right]\right)$.

In sum, CDS introduction could enhance debt value because creditors would receive the remaining firm value instead of the lowered face value of the renegotiated debt. However, the decreased monitoring intensity of creditors with CDS hurts the debt value after CDS introduction, because managers have an incentive to over-shirk, especially for the solvent states.

\section{Derivation of equation (A1)}

Expected value of debt before the CDS introduction is

$$
\begin{aligned}
& E_{0}\left[K \mid V_{1} \geq \bar{V}_{K}\left(\theta_{1}\right)\right] \cdot \operatorname{Pr}\left(V_{1} \geq \bar{V}_{K}\left(\theta_{1}\right)\right) \\
& +\xi E_{0}\left[K(1-L) \mid \bar{V}_{K(1-L)}\left(\theta_{1}\right) \leq V_{1}<\bar{V}_{K}\left(\theta_{1}\right)\right] \cdot \operatorname{Pr}\left(\bar{V}_{K(1-L)}\left(\theta_{1}\right) \leq V_{1}<\bar{V}_{K}\left(\theta_{1}\right)\right) \\
& +(1-\xi) E_{0}\left[V_{1}-\frac{V_{1}}{2 \theta_{1}} \mid \bar{V}_{K(1-L)}\left(\theta_{1}\right) \leq V_{1}<\bar{V}_{K}\left(\theta_{1}\right)\right] \cdot \operatorname{Pr}\left(\bar{V}_{K(1-L)}\left(\theta_{1}\right) \leq V_{1}<\bar{V}_{K}\left(\theta_{1}\right)\right) \\
& +E_{0}\left[V_{1}-\frac{V_{1}}{2 \theta_{1}} \mid V_{1}<\bar{V}_{K(1-L)}\left(\theta_{1}\right)\right] \cdot \operatorname{Pr}\left(V_{1}<\bar{V}_{K(1-L)}\left(\theta_{1}\right)\right) \\
& =K N\left(d_{2}\left(\phi_{1}\left(\theta_{1}\right), K\right)\right) \\
& +\xi K(1-L)\left[N\left(d_{2}\left(\phi_{1}\left(\theta_{1}\right), K(1-L)\right)\right)-N\left(d_{2}\left(\phi_{1}\left(\theta_{1}\right), K\right)\right)\right] \\
& +(1-\xi)\left(1-\frac{1}{2 \theta_{1}}\right) V_{0}\left[N\left(d_{1}\left(\phi_{1}\left(\theta_{1}\right), K(1-L)\right)\right)-N\left(d_{1}\left(\phi_{1}\left(\theta_{1}\right), K\right)\right)\right] \\
& \left(1-\frac{1}{2 \theta_{1}}\right) V_{0}\left[1-N\left(d_{1}\left(\phi_{1}\left(\theta_{1}\right), K(1-L)\right)\right)\right]
\end{aligned}
$$

\footnotetext{
${ }^{11} d_{2}\left(\phi_{1}\left(\theta_{2}\right), K\right)<d_{2}\left(\phi_{1}\left(\theta_{1}\right), K\right)$ if $\theta_{1}>\theta_{2}>1$.
} 
Expected value of debt after the CDS introduction is

$$
\begin{aligned}
& E_{0}\left[K \mid V_{1} \geq \bar{V}_{K}\left(\theta_{2}\right)\right] \cdot \operatorname{Pr}\left(V_{1} \geq \bar{V}_{K}\left(\theta_{2}\right)\right) \\
& +E_{0}\left[V_{1}-\frac{V_{1}}{2 \theta_{2}} \mid \bar{V}_{K(1-L)}\left(\theta_{2}\right) \leq V_{1}<\bar{V}_{K}\left(\theta_{2}\right)\right] \cdot \operatorname{Pr}\left(\bar{V}_{K(1-L)}\left(\theta_{2}\right) \leq V_{1}<\bar{V}_{K}\left(\theta_{2}\right)\right) \\
& +E_{0}\left[V_{1}-\frac{V_{1}}{2 \theta_{2}} \mid V_{1}<\bar{V}_{K(1-L)}\left(\theta_{2}\right)\right] \cdot \operatorname{Pr}\left(V_{1}<\bar{V}_{K(1-L)}\left(\theta_{2}\right)\right) \\
& =K N\left(d_{2}\left(\phi_{1}\left(\theta_{2}\right), K\right)\right) \\
& +\left(1-\frac{1}{2 \theta_{2}}\right) V_{0}\left[N\left(d_{1}\left(\phi_{1}\left(\theta_{2}\right), K(1-L)\right)\right)-N\left(d_{1}\left(\phi_{1}\left(\theta_{2}\right), K\right)\right)\right] \\
& \left(1-\frac{1}{2 \theta_{2}}\right) V_{0}\left[1-N\left(d_{1}\left(\phi_{1}\left(\theta_{2}\right), K(1-L)\right)\right)\right]
\end{aligned}
$$

where $\bar{V}_{K}(\theta)=\frac{K}{1-\frac{1-\alpha}{\theta}}, d_{1}(\phi, K)=\frac{\ln \left(\frac{V_{0}(1-\phi)}{K}\right)+\frac{\sigma^{2}}{2}}{\sigma}, d_{2}(\phi, K)=d_{1}(\phi, K)-\sigma$.

We obtain Equation (A2) by (A4) - (A3).

If we set $\theta_{1}=\theta_{2}=\theta$ in Equation (A3) and (A4), then we obtain (A1) by (A4) - (A3). 


\section{Appendix C. Variable definitions}

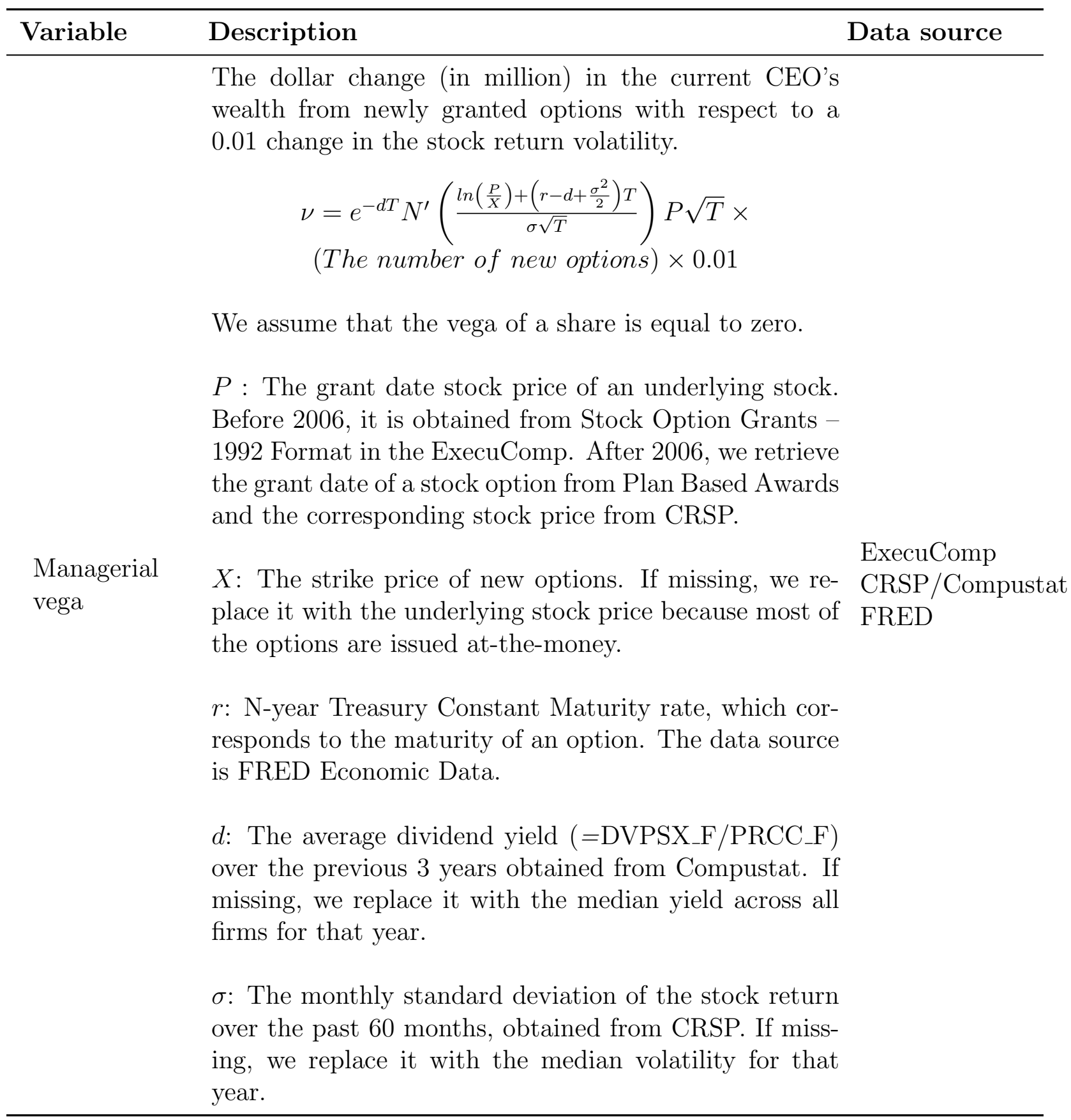




\begin{tabular}{|c|c|c|}
\hline Variable & Description & Data source \\
\hline & \multicolumn{2}{|l|}{$\begin{array}{l}\text { T: The time to maturity of the new option, which is the } \\
\text { difference between the grant date and the maturity of a } \\
\text { stock option in years. Before 2006, we assume the grant } \\
\text { date of an option as July 1st of the fiscal year, follow- } \\
\text { ing the convention of the ExecuComp. We obtain the } \\
\text { expiration date of an option from Stock Option Grants } \\
\text { - } 1992 \text { Format. After 2006, we match Outstanding Eq- } \\
\text { uity Awards and Plan Based Awards by CO_PER_ROL, } \\
\text { year, and exercise price. During the period, the grant } \\
\text { date is obtained from Plan Based Awards. If missing, } \\
\text { we replace it with the stock price on July 1st of the fiscal } \\
\text { year. The maturity date of an option is retrieved from } \\
\text { Outstanding Equity Awards. If we cannot calculate the } \\
\text { times to maturity from the process above, we set the } \\
\text { value equal to } 10 .\end{array}$} \\
\hline & $\begin{array}{l}\text { The number of new options: : The number of new } \\
\text { options granted to a CEO. Before 2006, it is equal to } \\
\text { numnewop in Stock Option Grants-1992 Format. After } \\
2006 \text {, it is obtained from Plan Based Awards. }\end{array}$ & \\
\hline $\begin{array}{l}\text { Managerial } \\
\text { option } \\
\text { delta }\end{array}$ & $\begin{array}{l}\text { The dollar change (in million) in the current CEOs } \\
\text { wealth from newly granted options, with respect to a } \\
0.01 \text { change in the stock price, multiplied by one hun- } \\
\text { dred for scaling. } \\
\qquad \Delta_{O}=e^{-d T} N\left(\frac{\ln \left(\frac{P}{X}\right)+\left(r-d+\frac{\sigma^{2}}{2}\right) T}{\sigma \sqrt{T}}\right) \times \\
\qquad \text { (The number of new options) }\end{array}$ & $\begin{array}{l}\text { ExecuComp } \\
\text { CRSP/Compusta } \\
\text { FRED }\end{array}$ \\
\hline
\end{tabular}




\begin{tabular}{|c|c|c|}
\hline Variable & Description & Data source \\
\hline & $\begin{array}{l}\text { The dollar change (in million) in the current CEO's } \\
\text { wealth from newly granted shares, with respect to a } 0.01 \\
\text { change in the stock price, multiplied by one hundred for } \\
\text { scaling. }\end{array}$ & \\
\hline & $\Delta_{S}=1 \times($ The number of new shares $)$ & \\
\hline $\begin{array}{l}\text { Managerial } \\
\text { share delta }\end{array}$ & $\begin{array}{l}\text { We assume that the delta of a share is equal to one. } \\
\text { The number of new shares: The number of new shares } \\
\text { granted to a CEO. Before } 2006 \text {, it is } R S T K G R N T \text { di- } \\
\text { vided by the strike price of newly granted options be- } \\
\text { cause options and shares are usually granted on a same } \\
\text { date and most of the options are issued at-the-money. If } \\
\text { the strike price is missing, we replace it with the average } \\
\text { stock price at the beginning and end of the fiscal year. } \\
\text { After 2006, it is the number of new shares granted to a } \\
\text { CEO, reported in Plan Based Awards. }\end{array}$ & $\begin{array}{l}\text { ExecuComp } \\
\text { CRSP/Compustat } \\
\text { FRED }\end{array}$ \\
\hline $\begin{array}{l}\text { Managerial } \\
\text { total delta }\end{array}$ & $\begin{array}{l}\text { The dollar change (in million) in the current CEO's } \\
\text { wealth from both newly granted options and shares with } \\
\text { respect to a } 0.01 \text { change in the stock price, multiplied } \\
\text { by one hundred for scaling. } \\
\qquad \Delta_{T}=\Delta_{O}+\Delta_{S}\end{array}$ & $\begin{array}{l}\text { ExecuComp } \\
\text { CRSP/Compustat } \\
\text { FRED }\end{array}$ \\
\hline $\mathrm{CDS}$ & $\begin{array}{l}\text { An indicator equal to one if a firm has traded a credit } \\
\text { default swap during the period of } 2001 \text { to } 2015 \text {. }\end{array}$ & Markit \\
\hline \multirow[t]{2}{*}{ Size } & $\ln (A T)$ & $\begin{array}{l}\text { Compustat } \\
\text { DATA6 }\end{array}$ \\
\hline & The natural logarithm of total assets. & \\
\hline $\begin{array}{l}\text { Market to } \\
\text { book }\end{array}$ & $\begin{array}{l}\qquad(M K V A L T+D L C+D L T T) / A T \\
\text { The sum of market capitalization, debt in current li- } \\
\text { abilities and long term debt divided by total assets. } \\
\text { If } M K V A L T \text { is missing, we replace it with } C S H O \times \\
P R C C_{-} F \text {. }\end{array}$ & $\begin{array}{l}\text { Compustat } \\
\text { DATA5, 6, 9, } \\
25,199\end{array}$ \\
\hline
\end{tabular}




\begin{tabular}{|c|c|c|}
\hline Variable & Description & Data source \\
\hline $\begin{array}{l}\text { Book } \\
\text { leverage }\end{array}$ & $\begin{array}{l}\qquad(D L C+D L T T) / A T \\
\text { The sum of debt in current liabilities and long term debt } \\
\text { divided by total assets. }\end{array}$ & $\begin{array}{l}\text { Compustat } \\
\text { DATA5, } 6,9\end{array}$ \\
\hline $\begin{array}{l}\text { ROA } \\
\text { volatility }\end{array}$ & $\begin{array}{l}\text { The quarterly standard deviation of operating income } \\
\text { before depreciation }(O I B D P Q) \text { divided by total assets } \\
(A T Q) \text { over the past three years. }\end{array}$ & $\begin{array}{l}\text { Compustat } \\
\text { Quarterly }\end{array}$ \\
\hline $\begin{array}{l}\text { Non-fixed } \\
\text { asset }\end{array}$ & $\begin{array}{l}\qquad 1-\frac{P P E N T}{A T} \\
\text { where PPENT is net property, plant, and equipment. }\end{array}$ & $\begin{array}{l}\text { Compustat } \\
\text { DATA6, } 8\end{array}$ \\
\hline $\mathrm{R} \& \mathrm{D}$ & $\begin{array}{l}\frac{X R D}{S A L E} \\
\text { where } X R D \text { is research and development expense. }\end{array}$ & $\begin{array}{l}\text { Compustat } \\
\text { DATA12, } 46\end{array}$ \\
\hline Non-utility & $\begin{array}{l}\text { An indicator equal to zero if the SIC code of a firm is } \\
\text { from } 4000 \text { to } 4999 \text { and one otherwise. }\end{array}$ & CRSP \\
\hline $\begin{array}{l}\mathrm{CEO} \\
\text { tenure }\end{array}$ & $\begin{array}{l}\text { The number of years since a CEO is assigned to a firm. } \\
\text { The date on which a CEO is assigned is identified by ei- } \\
\text { ther } B E C A M E C E O \text { or the beginning date of the fiscal } \\
\text { year in which a CEO is firstly identified by } C E O A N N \text {. } \\
\text { In some cases, the year in which a CEO firstly } \\
\text { appears (identified by } C E O A N N \text { ) is earlier than } \\
B E C A M E C E O \text {. Then we compare them and use an } \\
\text { earlier date. }\end{array}$ & ExecuComp \\
\hline $\begin{array}{l}\text { CEO } \\
\text { duality }\end{array}$ & $\begin{array}{l}\text { An indicator equal to one if a CEO is the chairman of } \\
\text { the board. }\end{array}$ & ISS \\
\hline
\end{tabular}


Figure 1. Managerial ownership and firm volatility as remedies of agency problem: The relevance of strategic default

This figure illustrates the relation of CEO's ownership $\alpha$ (or firm volatility $\sigma$ ), the probability of strategic default $\xi$, and agency cost $\Omega$.

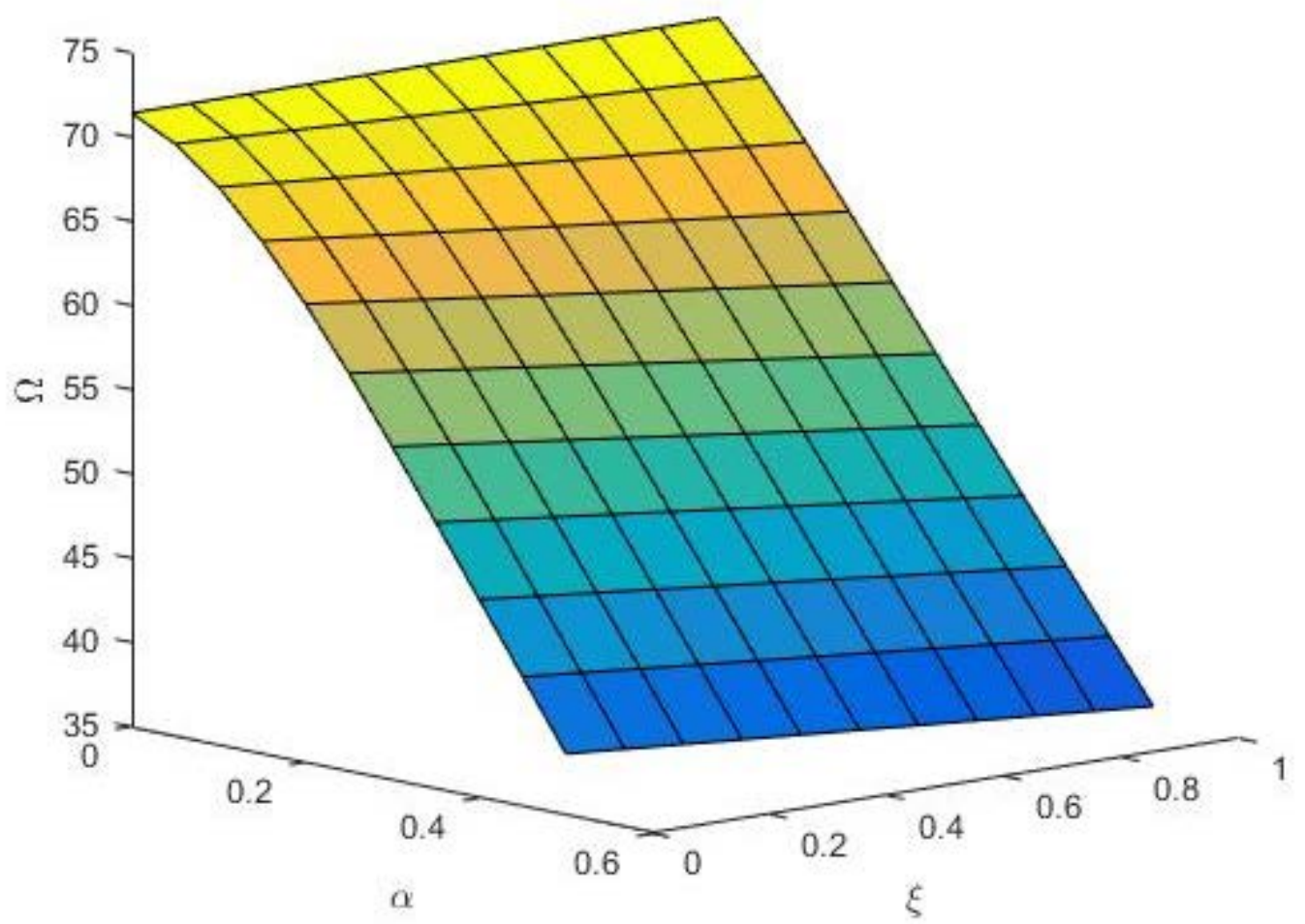

The relation of CEO's ownership $(\alpha)$, the probability of strategic default $(\xi)$, and agency cost $(\Omega)$.

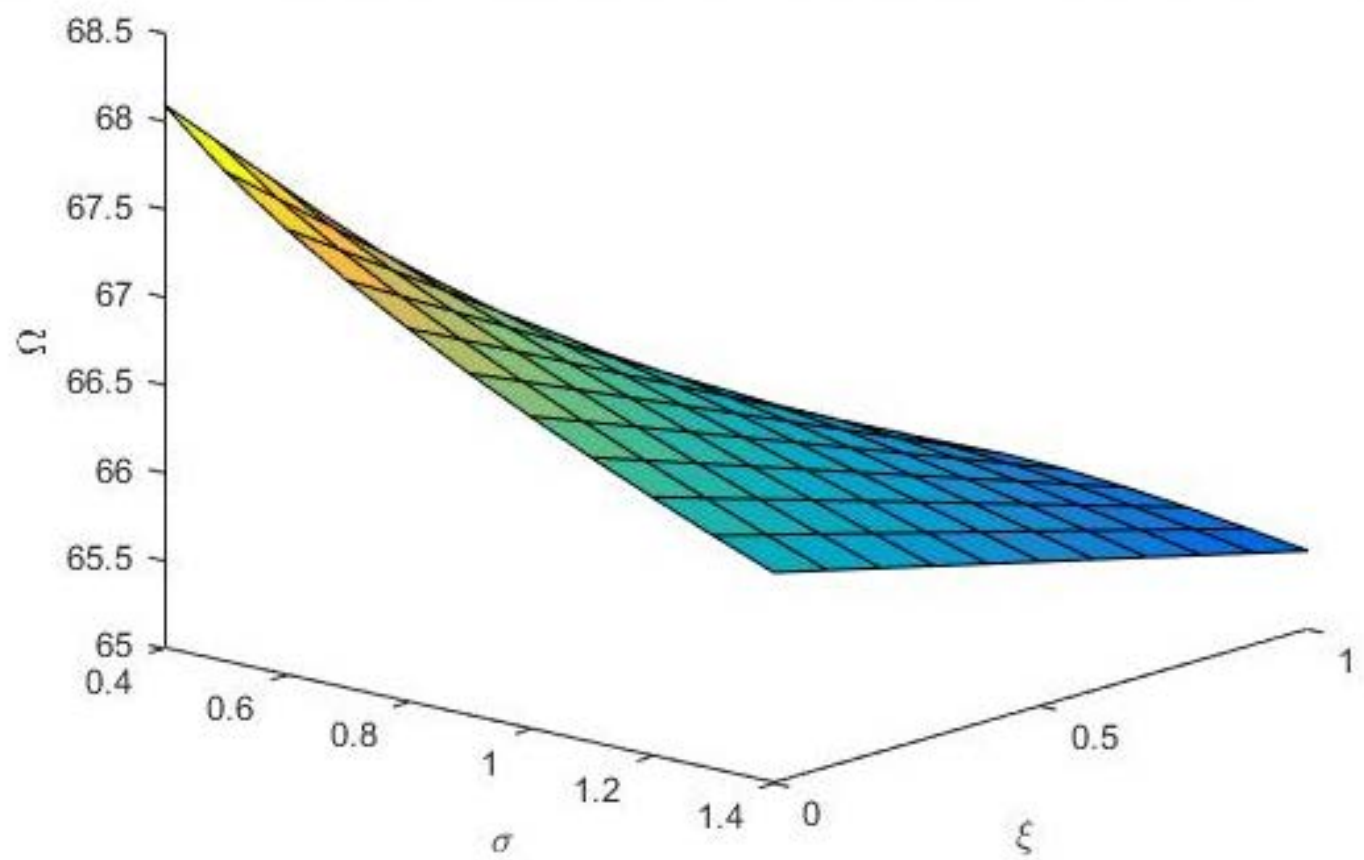

The relation of firm volatility $(\sigma)$, the probability of strategic default $(\xi)$, and agency cost $(\Omega)$. 


\section{Figure 2. Rating distribution after CDS inception}

This figure reports rating distribution for firms one year before CDS introduction (pre-CDS inception in the figure) and two years after CDS introduction(post-CDS inception in the figure). Our sample consists of 675 firms during the period from 2001 to 2015.

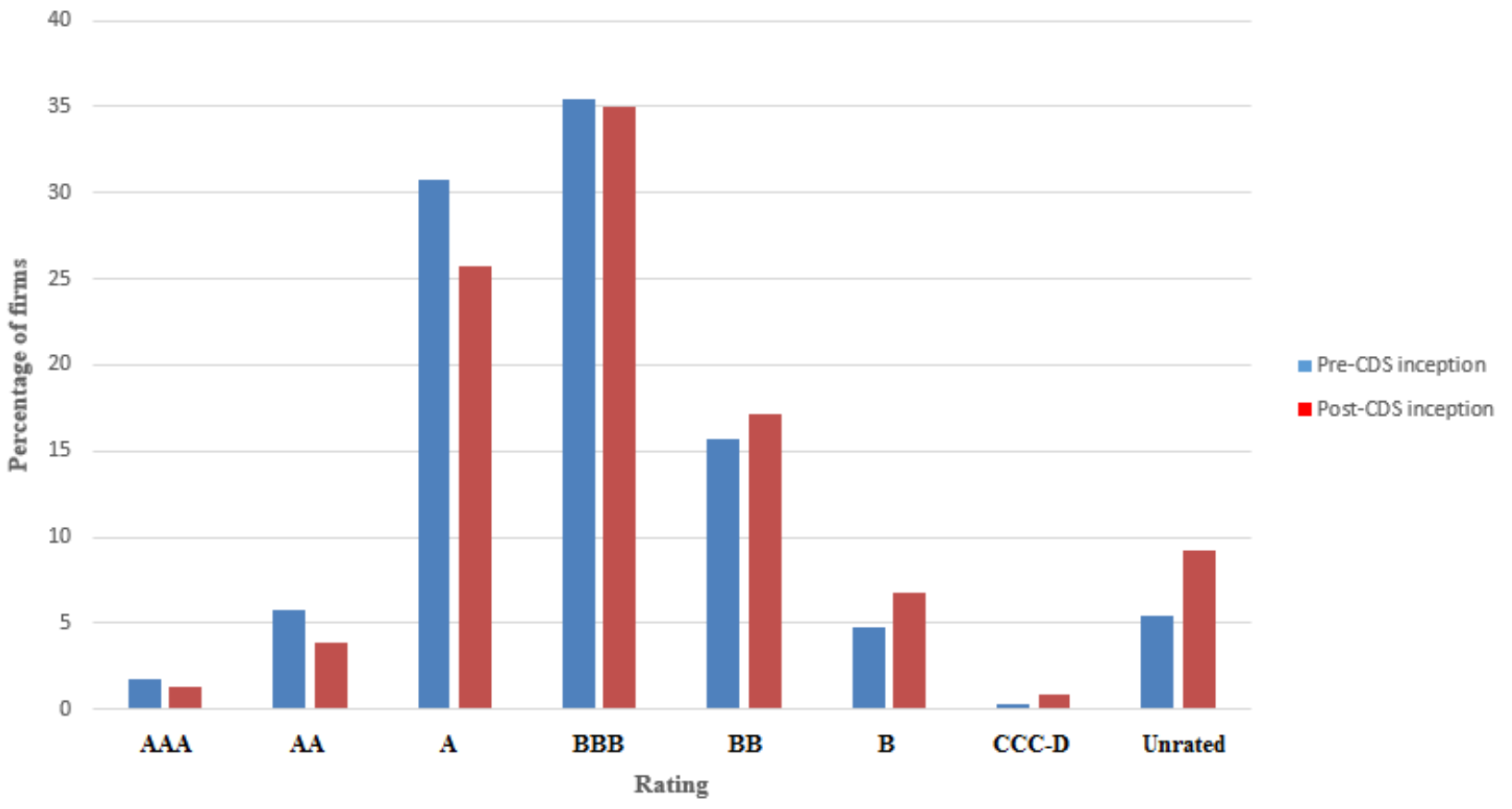




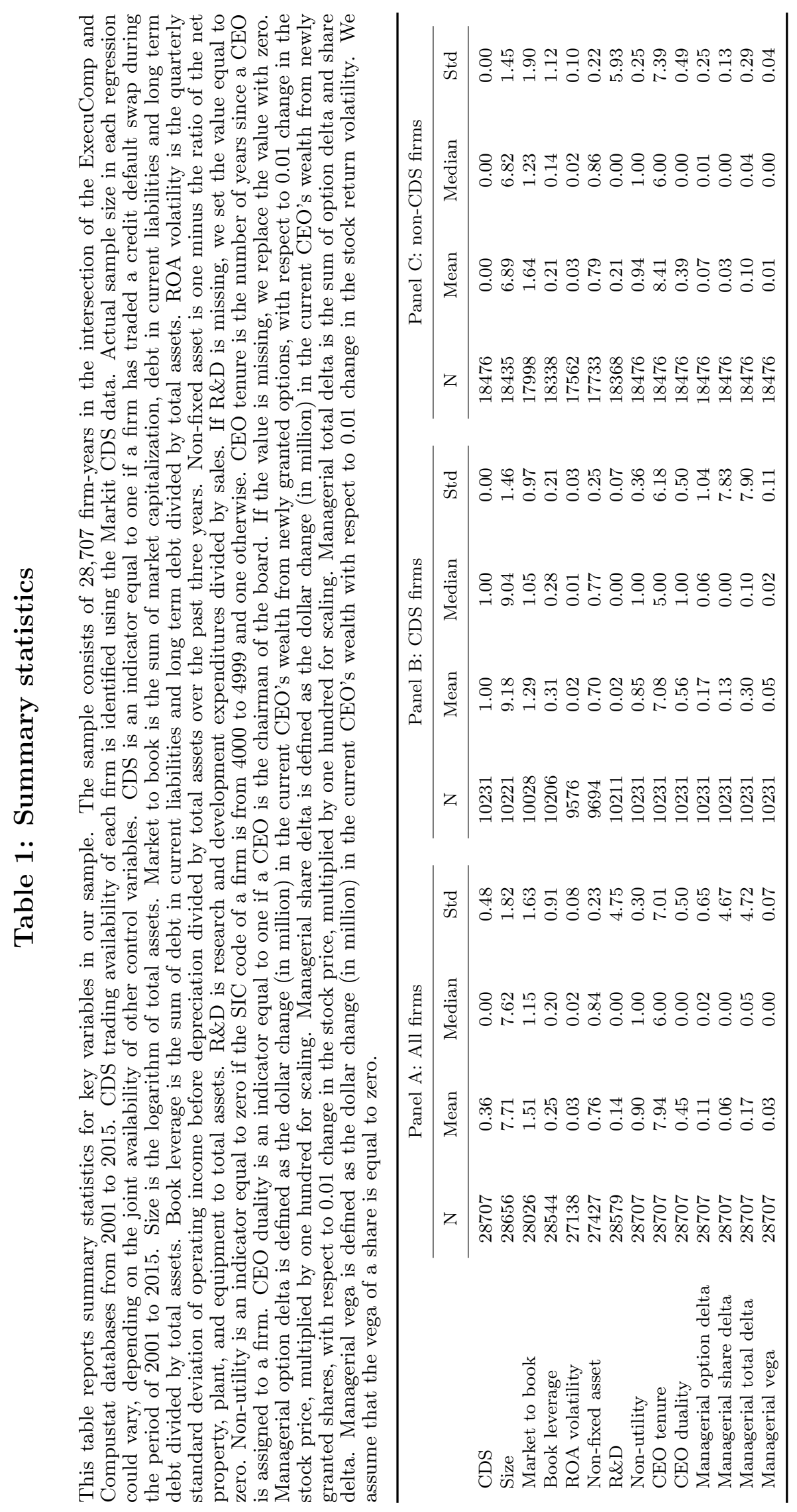




\section{Table 2: Managerial vega and CDS}

This table reports the CDS effect on CEO's managerial vega. Our sample consists of 28,707 firm-years in the intersection of the ExecuComp and Compustat databases from 2001 to 2015. CDS trading availability of each firm is identified using the Markit CDS data. Managerial vega is defined as the dollar change(in million) in the current CEO's wealth with respect to 0.01 change in stock return volatility. We assume that vega of a share is equal to zero. CDS is an indicator equal to one if a firm has traded a credit default swap during the period of 2001 to 2015 . Size is the logarithm of total assets. Market to book is the sum of market capitalization, debt in current liabilities and long term debt divided by total assets. Book leverage is the sum of debt in current liabilities and long term debt divided by total assets. ROA volatility is the quarterly standard deviation of operating income before depreciation divided by total assets over the past three years. Log Transform indicates that the dependent variable is replaced with the natural logarithm of 1 plus managerial vega. Industry group is defined by the first three digits of the SIC code. For OLS and Tobit with fixed effect, firm clustered standard errors are in parenthesis. For Tobit with random effect, bootstrapping robust standard errors are in parenthesis. AIC and BIC indicate Akaike information criterion and Bayesian information criterion, respectively. *, **, and *** denote significance levels of $10 \%, 5 \%$, and $1 \%$, respectively.

\begin{tabular}{|c|c|c|c|c|c|c|c|}
\hline & \multicolumn{7}{|c|}{ Dependent variables: Managerial vega } \\
\hline & & & $\begin{array}{l}\log \\
\text { transform }\end{array}$ & & $\begin{array}{l}\log \\
\text { transform }\end{array}$ & & $\begin{array}{c}\log \\
\text { transform }\end{array}$ \\
\hline & (1) & $(2)$ & $(3)$ & $(4)$ & $(5)$ & $(6)$ & (7) \\
\hline CDS & $\begin{array}{c}0.040^{* * *} \\
(0.003)\end{array}$ & $\begin{array}{c}0.009 * * * \\
(0.002)\end{array}$ & $\begin{array}{c}0.008^{* * *} \\
(0.002)\end{array}$ & $\begin{array}{c}0.040^{* * *} \\
(0.004)\end{array}$ & $\begin{array}{c}0.035^{* * *} \\
(0.004)\end{array}$ & $\begin{array}{c}0.011^{* * *} \\
(0.004)\end{array}$ & $\begin{array}{c}0.009^{* * *} \\
(0.003)\end{array}$ \\
\hline Size & & $\begin{array}{c}0.016^{* * *} \\
(0.001)\end{array}$ & $\begin{array}{c}0.014^{* * *} \\
(0.001)\end{array}$ & $\begin{array}{c}0.010^{* * *} \\
(0.001)\end{array}$ & $\begin{array}{c}0.008^{* * *} \\
(0.001)\end{array}$ & $\begin{array}{c}0.025^{* * *} \\
(0.002)\end{array}$ & $\begin{array}{c}0.022^{* * *} \\
(0.001)\end{array}$ \\
\hline Market to book & & $\begin{array}{c}0.008^{* * *} \\
(0.001)\end{array}$ & $\begin{array}{c}0.007^{* * *} \\
(0.001)\end{array}$ & $\begin{array}{c}0.010^{* * *} \\
(0.002)\end{array}$ & $\begin{array}{c}0.009^{* * *} \\
(0.001)\end{array}$ & $\begin{array}{c}0.011^{* * *} \\
(0.001)\end{array}$ & $\begin{array}{c}0.009^{* * *} \\
(0.001)\end{array}$ \\
\hline Book leverage & & $\begin{array}{c}-0.008^{* * *} \\
(0.001)\end{array}$ & $\begin{array}{c}-0.007^{* * *} \\
(0.001)\end{array}$ & $\begin{array}{c}-0.019^{* * *} \\
(0.005)\end{array}$ & $\begin{array}{c}-0.017^{* * *} \\
(0.005)\end{array}$ & $\begin{array}{c}-0.027^{* * *} \\
(0.006)\end{array}$ & $\begin{array}{c}-0.022^{* * *} \\
(0.005)\end{array}$ \\
\hline ROA volatility & & $\begin{array}{l}0.020^{*} \\
(0.011)\end{array}$ & $\begin{array}{l}0.016^{*} \\
(0.009)\end{array}$ & $\begin{array}{l}-0.008 \\
(0.031)\end{array}$ & $\begin{array}{l}-0.006 \\
(0.020)\end{array}$ & $\begin{array}{c}-0.001 \\
(0.014)\end{array}$ & $\begin{array}{l}-0.002 \\
(0.012)\end{array}$ \\
\hline Constant & $\begin{array}{c}0.014^{* * *} \\
(0.002)\end{array}$ & $\begin{array}{c}-0.116^{* * *} \\
(0.011)\end{array}$ & $\begin{array}{c}-0.102^{* * *} \\
(0.008)\end{array}$ & $\begin{array}{c}-0.110^{* * *} \\
(0.013)\end{array}$ & $\begin{array}{c}-0.090^{* * *} \\
(0.010)\end{array}$ & $\begin{array}{c}-0.172^{* * *} \\
(0.030)\end{array}$ & $\begin{array}{c}-0.141^{* * *} \\
(0.023)\end{array}$ \\
\hline Model & OLS & OLS & OLS & Tobit & Tobit & Tobit & Tobit \\
\hline Random effect & $\mathrm{N}$ & $\mathrm{N}$ & $\mathrm{N}$ & $\mathrm{Y}$ & $\mathrm{Y}$ & $\mathrm{N}$ & $\mathrm{N}$ \\
\hline Industry fixed effect & $\mathrm{Y}$ & $\mathrm{Y}$ & $\mathrm{Y}$ & $\mathrm{N}$ & $\mathrm{N}$ & $\mathrm{Y}$ & $\mathrm{Y}$ \\
\hline Year fixed effect & $\mathrm{Y}$ & $\mathrm{Y}$ & $\mathrm{Y}$ & $\mathrm{N}$ & $\mathrm{N}$ & $\mathrm{Y}$ & Y \\
\hline $\mathrm{N}$ & 25773 & 23903 & 23903 & 23946 & 23946 & 23903 & 23903 \\
\hline Adjusted R-square & 0.118 & 0.194 & 0.238 & & & & \\
\hline AIC & & & & -18100.55 & -24180.14 & -14328.72 & -20403.75 \\
\hline $\mathrm{BIC}$ & & & & -18035.88 & -24115.47 & -12364.85 & -18439.89 \\
\hline
\end{tabular}




\section{Table 3: Managerial option, share, total delta, and CDS}

This table reports the CDS effect on CEO's option delta, share delta, and total delta. Our sample consists of 28,707 firm-years in the intersection of the ExecuComp and Compustat databases from 2001 to 2015. CDS trading availability of each firm is identified using the Markit CDS data. Managerial option delta is defined as the dollar change (in million) in the current CEO's wealth from newly granted options, with respect to 0.01 change in the stock price, multiplied by one hundred for scaling. Managerial share delta is defined as the dollar change (in million) in the current CEO's wealth from newly granted shares, with respect to 0.01 change in the stock price, multiplied by one hundred for scaling. Managerial total delta is the sum of option delta and share delta. CDS is an indicator equal to one if a firm has traded a credit default swap during the period of 2001 to 2015. Size is the logarithm of total assets. Market to book is the sum of market capitalization, debt in current liabilities and long term debt divided by total assets. Book leverage is the sum of debt in current liabilities and long term debt divided by total assets. ROA volatility is the quarterly standard deviation of operating income before depreciation divided by total assets over the past three years. Log Transform indicates that the dependent variable is replaced with the natural logarithm of 1 plus the corresponding managerial delta. Industry group is defined by the first three digits of the SIC code. Firm clustered standard errors are in parenthesis. *, **, and *** denote significance levels of $10 \%, 5 \%$, and $1 \%$, respectively.

\begin{tabular}{|c|c|c|c|c|c|c|}
\hline \multirow{3}{*}{ Dependent variable } & \multicolumn{2}{|c|}{ Managerial option delta } & \multicolumn{2}{|c|}{ Managerial share delta } & \multicolumn{2}{|c|}{ Managerial total delta } \\
\hline & & $\begin{array}{c}\log \\
\text { transform }\end{array}$ & & $\begin{array}{c}\text { Log } \\
\text { transform }\end{array}$ & & $\begin{array}{c}\text { Log } \\
\text { transform }\end{array}$ \\
\hline & (1) & $(2)$ & (3) & (4) & $(5)$ & (6) \\
\hline CDS & $\begin{array}{c}0.031^{* *} \\
(0.013)\end{array}$ & $\begin{array}{c}0.020^{* * *} \\
(0.005)\end{array}$ & $\begin{array}{c}0.010^{* * *} \\
(0.004)\end{array}$ & $\begin{array}{c}0.009^{* * *} \\
(0.003)\end{array}$ & $\begin{array}{c}0.041^{* * *} \\
(0.014)\end{array}$ & $\begin{array}{c}0.026^{* * *} \\
(0.006)\end{array}$ \\
\hline Size & $\begin{array}{c}0.037^{* * *} \\
(0.006)\end{array}$ & $\begin{array}{c}0.023^{* * *} \\
(0.002)\end{array}$ & $\begin{array}{c}0.005^{* * * *} \\
(0.001)\end{array}$ & $\begin{array}{c}0.005^{* * *} \\
(0.001)\end{array}$ & $\begin{array}{c}0.042^{* * *} \\
(0.006)\end{array}$ & $\begin{array}{c}0.027^{* * * *} \\
(0.002)\end{array}$ \\
\hline Market to book & $\begin{array}{c}0.003 \\
(0.004)\end{array}$ & $\begin{array}{l}0.003^{*} \\
(0.002)\end{array}$ & $\begin{array}{c}-0.006^{* * *} \\
(0.001)\end{array}$ & $\begin{array}{c}-0.005^{* * *} \\
(0.001)\end{array}$ & $\begin{array}{l}-0.004 \\
(0.004)\end{array}$ & $\begin{array}{l}-0.001 \\
(0.002)\end{array}$ \\
\hline Book leverage & $\begin{array}{l}-0.004 \\
(0.004)\end{array}$ & $\begin{array}{l}-0.002 \\
(0.002)\end{array}$ & $\begin{array}{c}0.009^{* * *} \\
(0.002)\end{array}$ & $\begin{array}{c}0.007^{* * *} \\
(0.002)\end{array}$ & $\begin{array}{c}0.005 \\
(0.005)\end{array}$ & $\begin{array}{c}0.004 \\
(0.004)\end{array}$ \\
\hline ROA volatility & $\begin{array}{c}0.347 \\
(0.216)\end{array}$ & $\begin{array}{l}0.131^{*} \\
(0.068)\end{array}$ & $\begin{array}{c}0.055 \\
(0.035)\end{array}$ & $\begin{array}{c}0.034 \\
(0.021)\end{array}$ & $\begin{array}{l}0.402^{*} \\
(0.239)\end{array}$ & $\begin{array}{l}0.156^{*} \\
(0.082)\end{array}$ \\
\hline Constant & $\begin{array}{c}-0.263^{* * *} \\
(0.047)\end{array}$ & $\begin{array}{c}-0.158^{* * *} \\
(0.020)\end{array}$ & $\begin{array}{c}0.003 \\
(0.011)\end{array}$ & $\begin{array}{c}0.002 \\
(0.007)\end{array}$ & $\begin{array}{c}-0.260^{* * *} \\
(0.049)\end{array}$ & $\begin{array}{c}-0.147^{* * *} \\
(0.021)\end{array}$ \\
\hline Industry fixed effect & $\mathrm{Y}$ & $\mathrm{Y}$ & $\mathrm{Y}$ & $\mathrm{Y}$ & $\mathrm{Y}$ & $\mathrm{Y}$ \\
\hline Year fixed effect & $\mathrm{Y}$ & $\mathrm{Y}$ & $\mathrm{Y}$ & Y & $\mathrm{Y}$ & $\mathrm{Y}$ \\
\hline $\mathrm{N}$ & 23903 & 23903 & 23903 & 23903 & 23903 & 23903 \\
\hline Adjusted R-square & 0.017 & 0.151 & 0.027 & 0.060 & 0.023 & 0.155 \\
\hline
\end{tabular}




\section{Table 4: Managerial vega, CDS, and strategic default}

This table reports the CDS effect on managerial vega with strategic default proxies. Our sample consists of 28,707 firm-years in the intersection of the ExecuComp and Compustat databases from 2001 to 2015. CDS trading availability of each firm is identified using the Markit CDS data. The regression specifications are OLS with fixed effects. The dependent variable is managerial vega, which is defined as the dollar change(in million) in the current CEO's wealth with respect to 0.01 change in stock return volatility. We assume that vega of a share is equal to zero. CDS is an indicator equal to one if a firm has traded a credit default swap during the period of 2001 to 2015 . Size is the logarithm of total assets. Market to book is the sum of market capitalization, debt in current liabilities and long term debt divided by total assets. Book leverage is the sum of debt in current liabilities and long term debt divided by total assets. ROA volatility is the quarterly standard deviation of operating income before depreciation divided by total assets over the past three years. Strategic default proxy indicates variables such as non-fixed asset, market to book, R\&D, Non-utility, CEO tenure, and CEO duality, represented in the top row of each column. Non-fixed asset is one minus the ratio of the net property, plant, and equipment to total assets. R\&D is research and development expense divided by sales. If $\mathrm{R} \& \mathrm{D}$ is missing, we set the value equal to zero. Non-utility is an indicator equal to zero if the SIC code of a firm is from 4000 to 4999 and one otherwise. CEO Tenure is the number of years since a CEO is assigned to a firm. CEO duality is an indicator equal to one if a CEO is the chairman of the board. DiD marginal effect of RE Tobit indicates the marginal effect of difference-in-difference estimates of the interaction term (CDS)X(High strategic default proxy) in random effect Tobit model, where (High strategic default proxy) is defined as an indicator equal to one if the strategic default proxy is above median in our sample. Industry group is defined by the first three digits of the SIC code. For OLS with fixed effect, firm clustered standard errors are in parenthesis. For Tobit with random effect, bootstrapping robust standard errors are in parenthesis. *, **, and *** denote significance levels of $10 \%, 5 \%$, and $1 \%$, respectively.

\begin{tabular}{|c|c|c|c|c|c|c|}
\hline \multicolumn{7}{|c|}{ Dependent variables: Managerial vega } \\
\hline Strategic default proxies: & $\begin{array}{l}\text { Non-fixed } \\
\text { asset }\end{array}$ & $\begin{array}{c}\text { Market to } \\
\text { book }\end{array}$ & $\mathrm{R} \& \mathrm{D}$ & Non-utility & $\begin{array}{l}\text { CEO } \\
\text { tenure }\end{array}$ & $\begin{array}{c}\text { CEO } \\
\text { duality }\end{array}$ \\
\hline & $(1)$ & $(2)$ & $(3)$ & $(4)$ & $(5)$ & $(6)$ \\
\hline CDS & $\begin{array}{l}-0.010 \\
(0.007)\end{array}$ & $\begin{array}{l}-0.007 \\
(0.005)\end{array}$ & $\begin{array}{c}0.007^{* * *} \\
(0.002)\end{array}$ & $\begin{array}{l}-0.004 \\
(0.005)\end{array}$ & $\begin{array}{l}-0.000 \\
(0.007)\end{array}$ & $\begin{array}{c}0.002 \\
(0.003)\end{array}$ \\
\hline$(\mathrm{CDS}) \times($ Strategic default proxy $)$ & $\begin{array}{c}0.027^{* * *} \\
(0.011)\end{array}$ & $\begin{array}{c}0.011^{* * *} \\
(0.003)\end{array}$ & $\begin{array}{c}0.040 \\
(0.036)\end{array}$ & $\begin{array}{c}0.014^{* *} \\
(0.005)\end{array}$ & $\begin{array}{c}0.001 \\
(0.001)\end{array}$ & $\begin{array}{c}0.012^{* * *} \\
(0.004)\end{array}$ \\
\hline Strategic default proxy & $\begin{array}{c}0.009 \\
(0.005)\end{array}$ & & $\begin{array}{c}0.000^{* *} \\
(0.000)\end{array}$ & $\begin{array}{c}-0.023^{*} \\
(0.012)\end{array}$ & $\begin{array}{l}-0.000 \\
(0.000)\end{array}$ & $\begin{array}{l}-0.000 \\
(0.001)\end{array}$ \\
\hline Size & $\begin{array}{c}0.016^{* * *} \\
(0.001)\end{array}$ & $\begin{array}{c}0.016^{* * *} \\
(0.001)\end{array}$ & $\begin{array}{c}0.016^{* * *} \\
(0.001)\end{array}$ & $\begin{array}{c}0.016^{* * *} \\
(0.001)\end{array}$ & $\begin{array}{c}0.016^{* * *} \\
(0.001)\end{array}$ & $\begin{array}{c}0.016^{* * *} \\
(0.001)\end{array}$ \\
\hline Market to book & $\begin{array}{c}0.008^{* * *} \\
(0.001)\end{array}$ & $\begin{array}{c}0.006^{* * *} \\
(0.001)\end{array}$ & $\begin{array}{c}0.008^{* * *} \\
(0.001)\end{array}$ & $\begin{array}{c}0.008^{* * *} \\
(0.001)\end{array}$ & $\begin{array}{c}0.008^{* * *} \\
(0.001)\end{array}$ & $\begin{array}{c}0.008^{* * *} \\
(0.001)\end{array}$ \\
\hline Book leverage & $\begin{array}{c}-0.008^{* * *} \\
(0.001)\end{array}$ & $\begin{array}{c}-0.006^{* * *} \\
(0.002)\end{array}$ & $\begin{array}{c}-0.008^{* * *} \\
(0.001)\end{array}$ & $\begin{array}{c}-0.008^{* * *} \\
(0.001)\end{array}$ & $\begin{array}{c}-0.008^{* * *} \\
(0.001)\end{array}$ & $\begin{array}{c}-0.008^{* * *} \\
(0.001)\end{array}$ \\
\hline ROA volatility & $\begin{array}{l}0.019^{*} \\
(0.010)\end{array}$ & $\begin{array}{c}0.022^{* *} \\
(0.011)\end{array}$ & $\begin{array}{l}0.019^{*} \\
(0.010)\end{array}$ & $\begin{array}{l}0.021^{*} \\
(0.011)\end{array}$ & $\begin{array}{l}0.020^{*} \\
(0.011)\end{array}$ & $\begin{array}{l}0.020^{*} \\
(0.011)\end{array}$ \\
\hline Constant & $\begin{array}{c}-0.120^{* * *} \\
(0.011)\end{array}$ & $\begin{array}{c}-0.112^{* * *} \\
(0.011)\end{array}$ & $\begin{array}{c}-0.118^{* * *} \\
(0.011)\end{array}$ & $\begin{array}{c}-0.095^{* * *} \\
(0.016)\end{array}$ & $\begin{array}{c}-0.116^{* * *} \\
(0.011)\end{array}$ & $\begin{array}{c}-0.113^{* * *} \\
(0.012)\end{array}$ \\
\hline Industry fixed effect & Y & Y & Y & Y & Y & Y \\
\hline Year fixed effect & $\mathrm{Y}$ & $\mathrm{Y}$ & $\mathrm{Y}$ & $\mathrm{Y}$ & Y & $\mathrm{Y}$ \\
\hline $\mathrm{N}$ & 23606 & 23903 & 23848 & 23903 & 23903 & 23903 \\
\hline Adjusted R-square & 0.198 & 0.201 & 0.195 & 0.195 & 0.198 & 0.196 \\
\hline DiD marginal effect of RE Tobit & $\begin{array}{c}0.011^{* * *} \\
(0.003)\end{array}$ & $\begin{array}{c}0.012^{* * *} \\
(0.003)\end{array}$ & $\begin{array}{c}0.016^{* * * *} \\
(0.006)\end{array}$ & $\begin{array}{c}0.007 \\
(0.006)\end{array}$ & $\begin{array}{l}0.004^{*} \\
(0.002)\end{array}$ & $\begin{array}{c}0.004 \\
(0.004)\end{array}$ \\
\hline
\end{tabular}




\section{Table 5: Causal regression: IV approach}

This table reports instrumental variables regression with an instrument as lenders' bank foreign exchange derivative for hedging purpose(Lender FX derivative). Our sample consists of 28,707 firm-years in the intersection of the ExecuComp and Compustat databases from 2001 to 2015. CDS trading availability of each firm is identified using the Markit CDS data. Lender FX Derivative is defined as the average of foreign exchange derivative for non-trading purpose across all ultimate parents of a firm's lenders that have served as a lead arranger over the past five years. Column (1) is the first stage logit regressions of CDS on Lender FX derivative. Column (2) is the second stage OLS regression of managerial vega on fitted CDS in the first stage regression. Managerial vega is defined as the dollar change(in million) in the current CEO's wealth with respect to 0.01 change in stock return volatility. We assume that vega of a share is equal to zero. CDS is an indicator equal to one if a firm has traded a credit default swap during the period of 2001 to 2015. Size is the logarithm of total assets. Market to book is the sum of market capitalization, debt in current liabilities and long term debt divided by total assets. Book leverage is the sum of debt in current liabilities and long term debt divided by total assets. ROA volatility is the quarterly standard deviation of operating income before depreciation divided by total assets over the past three years. Industry and year fixed effect are controlled. Industry group is defined by the first three digits of the SIC code. Firm clustered standard errors are in parenthesis. $*, * *$, and $* * *$ denote significance levels of $10 \%, 5 \%$, and $1 \%$, respectively.

\begin{tabular}{|c|c|c|}
\hline \multirow{3}{*}{ Dependent variable } & 1st Stage & 2nd stage \\
\hline & CDS & Managerial vega \\
\hline & (1) & $(2)$ \\
\hline CDS & & $\begin{array}{c}0.024^{* * *} \\
(0.005)\end{array}$ \\
\hline Lender FX derivative & $\begin{array}{c}22.445^{* * *} \\
(3.260)\end{array}$ & \\
\hline Size & $\begin{array}{c}1.934^{* * *} \\
(0.099)\end{array}$ & $\begin{array}{c}0.013^{* * *} \\
(0.002)\end{array}$ \\
\hline Market to book & $\begin{array}{c}-0.125^{*} \\
(0.068)\end{array}$ & $\begin{array}{c}0.008^{* * *} \\
(0.001)\end{array}$ \\
\hline Book leverage & $\begin{array}{c}0.353^{* * *} \\
(0.093)\end{array}$ & $\begin{array}{c}-0.009^{* * *} \\
(0.001)\end{array}$ \\
\hline ROA volatility & $\begin{array}{l}-2.393 \\
(2.392)\end{array}$ & $\begin{array}{c}0.012 \\
(0.009)\end{array}$ \\
\hline Constant & $\begin{array}{c}-11.687^{* * *} \\
(1.152)\end{array}$ & $\begin{array}{c}-0.087^{* * *} \\
(0.012)\end{array}$ \\
\hline Industry fixed effect & Y & $\mathrm{Y}$ \\
\hline Year fixed effect & $\mathrm{Y}$ & $\mathrm{Y}$ \\
\hline $\mathrm{N}$ & 22029 & 19661 \\
\hline Pseudo R square & 0.579 & \\
\hline Adjusted R square & & 0.202 \\
\hline F statistics & & 25.896 \\
\hline
\end{tabular}

